\title{
PUBLIC PARTICIPATION AND THE PRIVATE SECTOR: THE ROLE OF MULTILATERAL DEVELOPMENT BANKS IN THE EVOLUTION OF INTERNATIONAL LEGAL STANDARDS
}

\author{
Daniel D. Bradlow* and Megan S. Chapman **
}

\begin{abstract}
This paper systematically describes the public participation standards currently applied by multilateral development banks (MDBs) to the private sector and seeks to identify emerging trends and areas for further development or improvement. It begins by outlining the developing body of international law on public participation and its relationship to good development practice. Thereafter, the paper describes the two principle models for standards attached to MDB funding and assistance to the private sector: (1) the World Bank policies applicable to the public sector; and (2) the International Finance Corporation (IFC) standards that are applicable to the private sector and how these are utilized in each of the principal regional MDBs: Inter-American Development Bank (IDB); the African Development Bank (AfDB); the Asian Development Bank (AsDB); and the European Bank for Reconstruction and Development (EBRD). Each subsection devoted to a regional MDB focuses on the substantive public participation standards with which private sector funding recipients must comply; and on the oversight and review mechanisms by which the MDB promotes and enforces compliance with these policies. The final part of the paper argues that the MDBs have taken a critical first step in extending public participation requirements to the private sector and are making important progress in enforcing such requirements. It urges the MDBs to recognise that they are, in fact, becoming creators of evolving international standards and norms or soft law. Consequently, in developing and interpreting their policies and standards, they should pay closer attention to other, more formal sources of international and domestic law on public participation.
\end{abstract}

Keywords: public participation, multilateral development banks, accountability, international soft law, private sector

\section{Introduction}

Over the past two decades, multilateral development banks (MDBs) have expanded ten-fold their funding to the private sector. ${ }^{1}$ This reflects the ever larger role that private companies are playing in development whether through privatised development projects, public-private partnerships, or foreign direct investment. In these operations, the MDBs require that their private sector financing recipients - like their public sector counterparts - comply with safeguard or sustainability policies that are designed to make MDBfunded projects more socially and environmentally sustainable. One key component of these policies is public participation through information disclosure, community consultation, and grievance mechanisms. Public participation requirements are justified

\footnotetext{
SARCHI Professor of International Development Law and African Economic Relations, University of Pretoria; Professor of Law, American University Washington College of Law; and Chair, Roster of Experts, Independent Review Mechanism, African Development Bank. The views expressed in this article are his personal views, and should not be attributed to any organisation with which he is affiliated.

Independent Consultant; B.A. University of Chicago; J.D. American University Washington College of Law. The authors wish to thank Anoush Begoyan, Andria Naude Fourie, Werner Kiene, Ellen Hey, David Hunter, Henrik Linders, Per Eldar Sovik, and our anonymous reviewers for comments on various sections and drafts.

ActionAid et al., 'Bottom Lines, Better Lives? Rethinking Multilateral Financing to the Private Sector in Developing Countries', Breton Woods Project, at 4 (2010) <http://www.brettonwoodsproject.org/ doc/private/privatesector.pdf $>$; for detailed statistics from each MDB, see below n. 79 (Inter-American Development Bank), n. 121-22 (African Development Bank), n. 154 (Asian Development Bank). The International Finance Company is devoted exclusively and the European Bank for Reconstruction and Development is devoted predominantly to private sector financing.
} 
on three grounds: (1) that development banks are financed primarily from public funds, ${ }^{2}$ and so should be accountable to member states' citizens $;^{3}$ (2) that public participation is an effective method by which to safeguard against unnecessary negative social and environmental impacts; ${ }^{4}$ and (3) that public participation is in and of itself essential for good (i.e. effective, sustainable, and inclusive) development. ${ }^{5}$ Consequently, each of the international and regional MDBs now incorporate public participation into their operational standards, their review procedures, their own organisational governance mechanisms and, at times, contractual conditions on financing to public and private sector recipients.

In developing and implementing social and environmental standards, the MDBs have looked to one another for models and have drawn, to some extent, on an emerging body of international law. As a result, despite a certain degree of regional and institutional variance, the MDBs tend to apply quite similar public participation requirements to both their public sector and private sector clients. The private sector appears to have accepted the value of such requirements as they have, for example, utilised the Performance Standards on Social and Environmental Sustainability, ${ }^{6}$ as set out by the International Finance Corporation (IFC), in developing a set of voluntary industry standards known as the Equator Principles that now apply to approximately ninety percent of emerging market project finance. ${ }^{7}$ These standards can further be extended to non-signatory private financial institutions through loan syndication and co-financing practices. Moreover, the most recent versions of MDB policies are now being drafted to ensure some level of consistency among major MDBs' policies ${ }^{8}$ and, where appropriate, to provide for project-level policy coordination among multiple funders. ${ }^{9}$

E.g. capital stock purchased by and direct donations from member state governments drawing upon public funds.

The disclosure policies of many of the MDBs, for example, proceed from the premise that use of public funds of member states makes the institutions directly accountable to the governments of member states and indirectly accountable to their citizens. E.g. African Development Bank, The African Development Bank Group Policy on Disclosure of Information,,(Oct. 2005) at 1.7, <http://www.afdb.org/fileadmin/ uploads/afdb/Documents/Policy-Documents/10000004-EN-THE-AFRICAN-DEVELOPMENT-BANKGROUP-POLICY-ON-DISCLOSURE-OF-INFORMATION.PDF> (stating 'the Bank Group recognizes that as custodians of public funds, it must seek to increase overall public understanding of development issues which, it is hoped, will engender increased support for the institution and its operations. The Bank and the Fund are directly accountable to their shareholders and State Participants and indirectly accountable to the legislatures and taxpayers of such shareholders and State Participants. Transparency of operations is an important element in ensuring this accountability').

4 E.g. International Finance Corporation [IFC], Policy on Social and Environmental Sustainability, (30 April 2006), at 8, (describing the IFC's aim that its investments 'do no harm' to people or the environment).

E.g. European Bank for Reconstruction and Development [EBRD], Performance Requirement 10: Information Disclosure and Stakeholder Analysis, (May 2008), at para. 1 (describing stakeholder engagement as 'central to achieving enhanced community benefits' not just to assessing and mitigating social and environmental risks).

6 IFC, IFC's Performance Standards on Social and Environmental Sustainability, (Apr. 30, 2006), at $1<$ http://www.ifc.org/ifcext/sustainability.nsf/AttachmentsByTitle/pol_PerformanceStandards2006_ full/\$FILE/IFC+Performance+Standards.pdf $>$ [hereinafter IFC's Performance Standards]. On 12 May 2011, the IFC Board approved an updated sustainability framework that will take effect on 1 January 2012. See, "Update on IFC's Policy and Performance Standards for Environmental and Social Sustainability and Access to Information Policy", April 14, 2011. Available at: http://www.ifc.org/ifcext/policyreview. nsf/AttachmentsByTitle/Board-Paper-IFC_SustainabilityFramework-2012/\$FILE/Board-Paper-IFC SustainabilityFramework-2012.pdf

W.B. Werther, Jr. \& D. Chandler, 'Strategic Corporate Social Responsibility: Stakeholders in a Global Environment' (2011), at 232.

8 For example, as part of the recent review of its environmental and social standards, the AsDB canvassed recent developments in other MDBs' social and environmental policies and used these to inform its own decisions, ensuring that its policy requirements are consistent with those of the World Bank, IFC, and the European Bank for Reconstruction and Development in order to promote potential harmonization; AsDB, Policy Paper: Safeguard Policy Statement, (June 2009), at 3, 12, Attachment 1 (Experience of Other Multilateral Financial Institutions), <http://www.adb.org/Documents/Policies/Safeguards/SafeguardPolicy-Statement-June2009.pdf $>$ [hereafter AsDB SPS Policy Paper].

9 E.g. EBRD, Environmental and Social Policy, (12 May 2008), at 10 ('The EBRD will work together with other international financial institutions, the EU, bilateral donors, UN agencies and other organisations in coordinating effective interventions to promote sustainable development at the regional or sectoral level 
The discussion below will systematically explore the public participation standards currently applied by MDBs to the private sector in order to identify emerging trends and areas for further development or improvement. As background, Part II will outline the developing body of international law on public participation and its relationship to good development practice. Part III will then introduce the two principle models for standards attached to MDB funding and assistance to the private sector: (1) the World Bank ${ }^{10}$ policies applicable to the public sector; and (2) the IFC standards that are applicable to the private sector. It will describe the public participation standards currently used by each of the principal regional MDBs: Inter-American Development Bank (IDB); the African Development Bank (AfDB); the Asian Development Bank (AsDB); and the European Bank for Reconstruction and Development (EBRD). ${ }^{11}$ Each sub-section devoted to a regional MDB will be organised so as to explain (1) the regional trend toward increased MDB funding to the private sector; (2) the substantive public participation standards with which private sector funding recipients must comply; and (3) the oversight and review mechanisms by which the MDB promotes and enforces compliance with these policies. The substantive public participation standards for each MDB will also be summarised in a comparative table in Annex I. Finally, Part IV will contain conclusions and recommendations. In brief, it will conclude that the MDBs have taken a critical first step in extending public participation requirements to the private sector and are making important progress in enforcing such requirements. However, it will also note that in doing so, MDBs ought to recognise that they are, in fact, becoming creators of evolving international standards and norms or soft law. ${ }^{12}$ Consequently, in developing and interpreting their policies and standards, they should pay closer attention to other, more formal sources of international and domestic law on public participation.

\section{Public Participation in International Law and Development Practice}

Since its emergence over the last two decades as an issue of global concern, public participation has been increasingly incorporated into national and organisational decision-making. ${ }^{13}$ The set of participatory rights entailed in the term public participation have their origins, at the national level, in the constitutional guarantees of democratic states and, at the international level, in human rights instruments and a developing body of international environmental law relating to sustainable development. The latter two bodies of international law have developed, in regard to participation, such standards as 'prior, informed consent' (PIC). ${ }^{14}$ Human rights law variously guarantees: (1) access to information as a component of the right of free speech; (2) the right to participate in

in its countries of operations. When co-financing projects with other international financial institutions, the EBRD will cooperate with them to agree on a common approach to project appraisal, project requirements, and monitoring').

${ }_{10}$ For these purposes the 'World Bank' refers to the International Bank for Recovery and Development (IBRD) and the International Development Association (IDA).

11 The one notable exclusion from this list is the European Investment Bank which, although it finances quite substantial private sector development in emerging markets, relies on European Union law to define and enforce its public participation requirements and thus does not fit easily into the broader trends and recommendations identified in this paper.

${ }_{12}$ There is no single definition of soft law, but it is often conceived of as law that is not enforceable but which does invoke some sense of obligation and which can result in adverse consequences in the event of non-compliance. There is an extensive literature on the topic. See also, e.g., A. T. Guzman and T. Meyer, 'International Soft Law', 2 Journal of Legal Analysis 1 (2011), and sources cited therein; J.J. Kirton and M. J. Trebilcock, Hard Choice, Soft Law: Voluntary Standards in Global Trade, Environment and Social Governance (2004) at 5-6. For a critical view, see, e.g., J. Klabbers, 'Soft Organizations in International Law', 70 Nordic Journal of International Law 402, (2001).

13 See C. Carmody, 'Beyond the Proposals: Public Participation in International Economic Law', 15 American University International Law Review 1321 (2000) at 1321-22 (describing efforts during the 1990s to make the Bretton Woods institutions more transparent and publicly accountable). See also the discussion of the Rio Declaration, below n. 17.

14 PIC is an important standard in numerous multilateral environmental agreements, including the Convention on Biological Diversity and the Basel Convention on Hazardous Wastes. See M. Nakagawa, 'Overview of Prior Informed Consent from an International Perspective', 4 Sustainable Development Law 
government; and (3) the right to access courts. These rights are incorporated into binding human rights instruments that are applied by the regional human rights bodies and international treaty bodies. ${ }^{15}$ These bodies have fleshed out the substantive dimensions of such rights by resolving complaints from indigenous and other communities that have challenged state-led development projects or state concessions to private companies. ${ }^{16}$

In addition, there are international soft law instruments that address public participation. These include the Rio Declaration on Environment and Development (Rio Declaration), which first laid out the three key elements of public participation for sustainable development, ${ }^{17}$ and the U.N. Declaration on the Rights of Indigenous People, which requires the 'free, informed, and prior consent' of indigenous peoples in a number of development project-related scenarios. ${ }^{18}$ There are also regional instruments that address the issue of public participation, such as the Convention on Access to Information, Public Participation in Decision-Making, and Access to Justice in Environmental Matters (Aarhus Convention), which has been widely adopted by

\& Policy 4 (2004). The 'free, prior, and informed consent' variation has more recently appeared in human rights instruments, most notably the UN Declaration on the Rights of Indigenous Peoples (see below n. 18.) 15 E.g., American Convention on Human Rights, July 18, 1978, O.A.S. Treaty Series No. 36, 1144 U.N.T.S. 123, Article 13 (Freedom of Thought and Expression). Includes as a component the 'right to seek [and] receive ... information' which has been interpreted by the Inter-American Court of Human Rights to ensure a public right of access to government information. See also Marcel Claude Reyes et al. v. Chile (2003), Case 12.108, Report No. 60/03, Inter-Am. C.H.R., OEA/Ser.L/V/II.118 Doc. 70 rev. 2 at 222; Julia GomesLund et al. v. Brazil, (2010), Case 11.552, Inter-Am. C.H.R. (not yet reported) <http://www.corteidh.or.cr/ docs/casos/articulos/seriec_219_esp.pdf $>$ (Spanish only). Article 23 guarantees the right to participate in government. Article 25 guarantees the right to protection of fundamental rights through prompt recourse to courts. Other regional and international human rights instruments contain similar guarantees.

16 E.g. an important line of cases from the Inter-American human rights system have found state violations of indigenous communities' procedural rights: access to information about proposed concessions and development projects; community participation through ongoing consultation processes, followed by an informed consent requirement; and access to judicial remedies pursuant to Article 25 of the American Convention on Human Rights. See D. Shelton, 'Environmental Rights and Brazil's Obligations', 40 George Washington International Law Review 733 (2009) at 768-774; Generally, if a state fails to provide required procedural protections, the indigenous community may file a petition with the Inter-American Commission on Human Rights, which may grant precautionary measures and attempt to work towards friendly settlement with the state. See, e.g. Maya Indigenous Communities of the Toledo District v. Belize, (2004), Case 12.053, Inter-Am. C.H.R., Report No. 40/04 (holding the state responsible for violating the Toledo Maya's rights to property, equality, and judicial protection under the American Declaration for granting logging and oil concessions on indigenous lands and delaying court proceedings in which the Maya sought to challenge these acts); Sawhoyamaxa Indigenous Community v. Paraguay Case, (2006) Inter-Am. Ct. H.R. (ser. C) No. 146 (Mar. 29, 2006); The Kichwa Peoples of the Sarayaku Community and Its Members v. Ecuador, (2004), Case No. 12.465, Inter-Am. C.H.R., Report No. 64/04. The InterAmerican human rights system handles numerous cases involving development projects approved by states without required procedural protections for affected communities. See, e.g. Ngöbe Indigenous Communities and Their Members in the Changuinola River Valley v. Panama, (2009), Pet. No. 286-08, Inter-Am. C.H.R., Rep. No. 175/09 (declaring admissible a case filed by indigenous communities in Panama to challenge a government concession for a hydroelectric dam project on ancestral lands without prior consultation); Diaguita Agricultural Communities of the Huasco-Altinos and the Members Thereof $v$. Chile, (2009), Pet. No. 415-07, Inter-Am. C.H.R., Rep. No. 141/09, (declaring admissible a petition filed by indigenous communities in Chile challenging the government's environmental approval of a mining project on ancestral lands without taking into account the community's views on the risks). At least one similar case has been decided by the African Commission on Human and Peoples' Rights (ACHPR), which found that the Kenyan government's eviction of the Endorois indigenous community without consultation or compensation, violated inter alia their right to dignity: Centre for Minority Rights Development (Kenya) and Minority Rights Group International on behalf of Endorois Welfare Council v Kenya, (2009), ACHPR Comm. No. 276/2003 (The European Court of Human Rights (ECHR) has handled different cases relating to the public's right to information regarding environmental issues. See, e.g. Bladet Tromso and Stensaas v. Norway, ECHR, (1999), Application No. 21980/93.

17 Rio Declaration on Environment and Development, principle 10, U.N. Doc. A/CONF.151/26, 3-14 June 1992. [hereafter Rio Declaration] (identifying the three elements of public participation essential to best practice for national-level handling of environmental issues as (1) access to information, (2) participation in decision-making, and (3) redress of grievances).

18 U.N. Declaration on the Rights of Indigenous Peoples, General Assembly Resolution 61/295, 13 Sept. 2007. 
members of the U.N. Economic Commission for Europe (UNECE) ${ }^{19}$ and the InterAmerican Strategy for the Promotion of Public Participation in Decision Making for Sustainable Development, which has been adopted by the Organization of American States (OAS). ${ }^{20}$

Underpinning this advancement is a fundamental shift in our understanding of good development practice. Rather than viewing public participation as a collateral matter of individual rights unconnected to positive economic development (as has been the traditional view), the modern perspective of development is more holistic. In the modern conception, public participation is seen as an essential component of socially and environmentally sustainable development ${ }^{21}$ that can counteract the tendency of those who plan, promote, and implement development projects to underestimate the projects' social and environmental disadvantages. ${ }^{22}$ Moreover, public participation can also be positively conceived as a method of ensuring that development projects actually benefit those affected communities that will be expected to make the tradeoffs and sacrifices that may be associated with a project.

\section{MDBs and Evolving Public Participation Requirements for the Private Sector}

The two principal models for current MDB standards on public participation are the IFC's Performance Standards (outlined in detail below) and the World Bank's Safeguard Policies. Although the current trend seems to lead towards adopting the IFC model, the World Bank's Safeguard Policies, although drafted to apply to the public sector, are important because they were the first set of MDB standards to incorporate public participation. The IFC, which only finances the private sector, and other MDBs that finance both the private and public sectors, initially adopted policies modelled on the Safeguard Policies. These public sector-oriented policies have since been gradually modified to reflect, in part, the MDBs' experience of applying them to the private sector.

In general, the earlier standards (e.g. those of the IDB and the AfDB) draw heavily on the World Bank Safeguard Policy as a model. Those MDBs that have adopted or revised their standards more recently (e.g. those of the AsDB and the EBRD) are more heavily influenced by the IFC Performance Standards approach. The same influences can be seen in the MDBs' development of disclosure policies and independent complaint mechanisms. Beyond such inter-MDB influences, each of the regional development banks responds to the particular concerns of its regional political body and may look to regional instruments relating to human rights or sustainable development.

The World Bank's Safeguard Policies will not be discussed in detail below since they only apply directly to the public sector. ${ }^{23}$ Their basic structure is worth outlining briefly as its influence can be seen in the policies of some of the other MDBs. The Safeguard Policies are comprised of ten operational policies that apply social and environmental safeguards to all projects supported by the International Bank for Reconstruction and Development (IBRD) and the International Development Association (IDA). ${ }^{24}$ The

\footnotetext{
19 Convention on Access to Information, Public Participation in Decision-Making, and Access to Justice in Environmental Matters, June 25, 1998, 2161 U.N.T.S. 447 [hereinafter Aarhus Convention].

20 Organization of American States [OAS], Inter-American Strategy for the Promotion of Public Participation in Decision Making for Sustainable Development (13 March 1999) < http://www.oas.org/dsd/ PDF_files/ispenglish.pdf $>$.

21 See, generally, D.D. Bradlow, 'Differing Conceptions of Development and the Content of International Development Law', 21 South African Journal on Human Rights 1 (2005); Shahid Yusuf et al., 'Development Economics through the Decades - A Critical Look at Thirty Years of the World Development Report' (2009) at 35.

22 Id.

23 Note, however, that these standards may become applicable to private sector actors through the procurement contracts concluding during project implementation by public sector project promoters.

24 The Safeguard Policies' framework is Operational Policy (OP) 4.01, Environmental Assessment (1999), which works in conjunction with nine more specific policies: OP 4.04, Natural Habitats (2001); OP 4.09, Pest Management (1998); OP 4.10, Indigenous Peoples (July 2005); OP 4.11, Physical Cultural Resources (2006); OP 4.12, Involuntary Resettlement (2001); OP 4.36, Forests (2002); OP 4.37, Safety of
} 
fundamental requirement is that the project proponent conducts an assessment of the project's environmental and social impacts prior to project approval. In the case of projects that the World Bank has categorized as entailing some level of social or environmental risk (Category A or B), the assessment process must include disclosure of information to and consultation with potentially affected communities and local NGOs. ${ }^{25}$ Additional disclosure and consultation may be required if the project involves involuntary resettlement, physical cultural resources, or indigenous communities. ${ }^{26}$ Each of the operational policies describes the responsibilities of the borrower to make disclosures and carry out consultations, and of the World Bank to advise, oversee, and ensure borrower compliance. The World Bank must also make project-related disclosures under its Access to Information Policy. ${ }^{27}$ One mechanism for ensuring Bank-level compliance with these policies is the World Bank's Inspection Panel, which conducts compliance investigations based on complaints from communities and people adversely affected by Bank-financed projects.

One noteworthy trend in the evolution of MDBs' policies on public participation along with other social and environmental safeguards is the move to increasingly place responsibility for compliance and the details of implementation on the borrowerwhether private or public sector. This is consistent with one of the goals of the Paris Declaration on Effectiveness of International Aid (Paris Declaration) ${ }^{28}$ to better utilize national country systems. ${ }^{29}$ In 2005 , the World Bank adopted a two-year pilot program to allow borrowing member countries to demonstrate on a project-by-project basis the equivalence of their country safeguard systems, including mechanisms for public participation, to the requirements of the Safeguard Policies. The World Bank has continued this policy since its pilot phase. ${ }^{30}$

The IFC Performance Standards' focus on its clients' internal management systems for public participation and other social and environmental safeguards arguably parallels the national systems' approach. As will be seen below, there is a trend in safeguard policies towards -clearer delineation of borrowers' and MDBs' responsibilities policies, in some cases with additional terms and conditions in the loan agreements that enhance enforceability.

For each of the MDBs discussed below, this paper will first look at the extent to which each finances the private sector. The first sub-section outlines how standards applicable to private sector projects incorporate the three elements of public participation first identified in the Rio Declaration - (1) disclosure and access to information; (2) consultation and participation in decision-making; and (3) access to judicial or quasijudicial review with some form of dispute resolution or remedies available ${ }^{31}-$ as well

Dams (2001); OP 7.50, International Waterways (2001); and OP 7.60, Operations in Disputed Areas (2001). Member countries are encouraged to adopt these or equivalent safeguards into their national projectplanning systems. OP 4.00, Piloting the Use of Borrower Systems to Address Environmental and Social Safeguard Issues in Bank-Supported Projects (2005).

25 Operational Policy (OP) 4.01, Environmental Assessment (1999), at paras. 8, 14-18.

26 OP 4.10, Indigenous Peoples (July 2005); OP 4.11, Physical Cultural Resources (2006), at paras. 11-12; OP 4.12, Involuntary Resettlement (2001), at paras 9, 14 .

$27<$ http://web.worldbank.org/WBSITE/EXTERNAL/PROJECTANDOPERATIONS/EXTINFODISC LOSURE/0,,menuPK:64864911 pagePK:4749265 piPK:4749256 theSitePK:5033734,00.html> (last visited 10 Feb. 2011).

28 Organisation for Economic Cooperation and Development [OECD], The Paris Declaration on Aid Effectiveness [Paris Declaration] (2005) and the Accra Agenda for Action [AAA] (2008), at 6-8, <http:// www.oecd.org/dataoecd/30/63/43911948.pdf $>$ (outlining partner countries' and donors' commitments to harmonising standards in order to promote more effective aid) [hereinafter Paris Declaration and the AAA]. The international organisations adhering to the Paris Declaration and the AAA include the World Bank, Inter-American Development Bank, Asian Development Bank, African Development Bank, European Bank for Reconstruction and Development, and the European Investment Bank. OECD, Countries, Territories and Organisations Adhering to the Paris Declaration and AAA, $<$ http://www.oecd.org/document/22/0,3746 ,en_2649_3236398_36074966_1_1_1_1,00.html > (last visited 7 Feb. 2011).

29 Paris Declaration and the $\overline{\mathrm{AAA}} \overline{\mathrm{A}}$, above n. 28 , at 4.

30 The World Bank has also since floated a proposal to recognise a country's national system equivalence beyond a project-by project basis, which remains controversial.

31 The Rio Declaration first identified these three elements of public participation as essential to a best practice for national-level handling of environmental issues. Rio Declaration, above n. 17, at principle 
as human rights participation principles, particularly those applicable to indigenous peoples. ${ }^{32}$ The next sub-section then identifies how each policy framework divides responsibilities between the borrower and bank and ensures both borrower and bank compliance with their respective requirements. Thus, the following offers a one-stop compendium on the MDB public participation standards where no such resource exists.

\subsection{International Finance Corporation (IFC)}

The International Finance Corporation (IFC) is the private sector funding entity of the World Bank Group. It has positioned itself as a leader in promulgating standards linking private sector accountability for environmental and social impacts to international environmental and, to a lesser extent, human rights law. ${ }^{33}$ In 2006, the IFC issued eight updated Performance Standards that, in theory, should apply to all clients receiving IFC financing throughout the life of the investment. ${ }^{34}$ However, the standards classify projects according to the level of social and environmental risks, and in practice, the standards only fully apply to projects in the highest risk category. ${ }^{35}$

The standards replaced the then eight-year-old IFC Safeguard Policies. ${ }^{36}$ They modified the prior policies to make them more suitable to the private sector, most notably by separating the standards that a funding recipient must apply from the broader policies governing IFC operations, project approval, and oversight. To further assist private sector clients implementing these Performance Standards, the IFC has a number of guidance documents. The Guidance Notes provide additional explanation for each Performance Standard, while reaffirming that each client must exercise judgment in how best to implement the requirements according to its particular business context. ${ }^{37}$ Several additional guidance documents focus on best practices for community and stakeholder engagement. ${ }^{38}$

10. These three elements were formalized at the regional level in the 1998 Aarhus Convention. Aarhus Convention, above n. 19.

32 See, e.g., the IFC 2012 Performance Standard 1, below at n. 42, which incorporates the term 'free, prior, informed consent, making implicit reference to the U.N. Declaration on the Rights of Indigenous Peoples (UNDRIP). The EBRD Performance Requirement 7: Indigenous Communities, below at n. 218, goes one step further, actually adopting the term with specific citation to the UNDRIP.

33 E. Morgera, 'Significant Trends in Corporate Environmental Accountability: The New Performance Standards of the International Finance Corporation', 18 Colorado Journal of International Environmental Law \& Policy 152 (2007). On the emerging incorporation of international human rights standards, at least with regard to the rights of indigenous persons, see discussion below at n. 68 .

34 IFC, IFC's Performance Standards on Social and Environmental Sustainability, (Apr. 30, 2006), at 1 (Introduction), <http://www.ifc.org/ifcext/sustainability.nsf/AttachmentsByTitle/pol PerformanceStandards2006 full/\$FILE/IFC+Performance+Standards.pdf $>$ [hereinafter 2006 IFC Performance Standards].

35 Private e-mail from IFC staff member to authors, April 8, 2011 (on file with authors) [hereafter IFC e-mail]. As will be seen in discussion below, when a project is classified into a lower risk category (B or C), many of the Performance Standards related to 'adverse outcomes' no longer apply; similarly, while the Performance Standards do apply to financial institutions (FI) clients, they do not necessarily extend to apply to those projects in turn funded by the FIs.

36 M. Warner, 'The New International Benchmark Standard for Environmental and Social Performance of the Private Sector in Developing Countries: Will It Raise or Lower the Bar?', 66 Overseas Development Institute Opinions 1 (2006), <http://www.odi.org.uk/resources/download/510.pdf>.

37 IFC, IFC's Guidance Notes: Performance Standards on Social \& Environmental Sustainability, (31 July 2007), at 1 (Introduction, at paras. 1-2) <http://www.ifc.org/ifcext/sustainability.nsf/AttachmentsByTitle/ pol_GuidanceNote2007_full/\$FILE/2007+Updated+Guidance+Notes_full.pdf> [hereinafter IFC's Guidance Notes]. Note that the flexibility of permissible implementation and the very existence of the Guidance Notes may undercut the certainty of what an IFC client is actually required to do and allows the requirements to be to some extent negotiable.

${ }^{38}$ See, e.g. IFC, Doing Better Business through Effective Public Consultation and Disclosure: A Good Practice Manual, (1998). <http://www.ifc.org/ifcext/sustainability.nsf/AttachmentsByTitle/p pubconsult/\$FILE/PublicConsultation.pdf>; IFC, Stakeholder Engagement: A Good Practice Handbook for Companies Doing Business in Emerging Markets (2007) <http://www.ifc.org/ifcext/sustainability.nsf/ AttachmentsByTitle/p_StakeholderEngagement_Full/SFILE/IFC_StakeholderEngagement.pdf>. 
The remainder of this section reviews the 2006 Performance Standards as they relate to public participation requirements and the mechanisms in place to ensure compliance with them. It should be noted that the IFC Performance Standards, the IFC Policy on Social and Environmental Sustainability, and the IFC Disclosure of Information Policy, underwent a review that began in 2009. On 12 May 2011, the IFC Board approved an updated sustainability framework that will take effect on 1 January 2012. The most significant differences between the current 2006 standards and those that will take effect in 2012 will be highlighted below.

\subsubsection{Performance Standards for Private Sector Clients}

Performance Standard 1 (Social and Environmental Assessment and Management System) lays the framework for sustainability, based on the initial impact assessment, community engagement, and ongoing project management. The remaining seven standards establish more specific requirements 'to avoid, reduce, mitigate or compensate for impacts on people and the environment, and to improve conditions where appropriate' ${ }^{39}$

'Community engagement' is an essential part of the initial impact assessment described in Performance Standard 1; its purpose is 'to build and maintain over time a constructive relationship' with affected communities. ${ }^{40}$ The scope and regularity of community engagement varies depending on the nature of the project's 'adverse impacts' ${ }^{41}$ The new 2012 Performance Standard 1 substitutes the term 'stakeholder engagement', for "community engagement", indicating that a broader set of constituencies should be engaged, but uses similar language to describe the purpose and scope of the engagement required when there are 'affected communities' ${ }^{42}$ Under both the 2006 and the new 2012 standards, it is unclear who is meant to determine the scope of the engagement initially required. While the IFC itself categorises projects (Category A for significant adverse impacts, B for lesser adverse impacts that can be mitigated, and $\mathrm{C}$ for no adverse impacts) before they are sent for approval by the IFC Board of Directors, this categorisation relies on the client's impact assessment process, which itself may have different community engagement requirements. ${ }^{43}$

'Community engagement' is defined ${ }^{44}$ in order to encompass, without explicit reference, the three Rio Declaration elements of public participation derived from international environmental and human rights law. ${ }^{45}$ Performance Standard 1 elaborates on the specific requirements for client disclosure, consultation, and establishment of a grievance mechanism, which can be summarised as follows:

39 IFC 2006 Performance Standards, above n. 34, at 1 (Introduction).

40 Id. at 4 (Performance Standard 1, at para. 19).

41 Id. The notion that the scope of the impact assessment will be tailored to the nature of the project and potential risks runs throughout Performance Standard 1. Id. at 2 (Performance Standard 1, at paras. 8-9)

42 IFC, Performance Standard 1: Assessment and Management of Environmental and Social Risks and Impacts, (1 Jan. 2012), at paras. 25-33 [hereinafter IFC 2012 Performance Standard 1].

43 IFC, IFC's Policy on Social and Environmental Sustainability, (30 April 2006), at para.18<http:// www.ifc.org/ifcext/sustainability.nsf/AttachmentsByTitle/pol_SocEnvSustainability2006/\$FILE/ SustainabilityPolicy.pdf $>$ [hereafter IFC 2006 Policy on Social and Environmental Sustainability]. Because the IFC often enters as a funder later in the project cycle rather than at the outset, more sophisticated clients will have gone through project planning and impact assessment with an eye to meeting IFC Performance Standards. While such client awareness and preparation is in many ways a positive, it also may mean that clients have conducted impact assessment and project risk classifications so they meet all their own procedural requirements, but such strict procedural compliance may disguise the real scope of project challenges. Another challenge with this approach to risk classification is that the assessment of project impacts may artificially end at the individual project's fence line although environmental impacts may actually extend through an entire water- or air-shed. IFC e-mail, above n. 35.

${ }_{44}$ The glossary accompanying the 2006 Performance Standards defines it as 'an on-going process involving disclosure of information, consultation with affected communities, and the establishment of a grievance mechanism'.IFC, Glossary of Terms: IFC Policy \& Performance Standards and Guidance Notes, June 6, 2006, <http://www.ifc.org/ifcext/sustainability.nsf/AttachmentsByTitle/pol_PerformanceStandards2006_ glossary/\$FILE/Glossary+of+Terms.pdf>.

45 Rio Declaration, above n. 17. 
- Disclosure. The guiding principle is disclosure of 'timely, relevant, understandable and accessible information. ${ }^{46}$ The client must publicly disclose its social and environmental assessment document, a draft document (rather than a final report) that will assist affected communities to engage during the assessment process. For projects that are determined to have 'adverse social or environmental impacts', 'disclosure should occur early in the ... assessment process and in any event before the project construction commences, and [thereafter] on an ongoing basis'. ${ }^{47}$ Such disclosure must be made to any communities that may be affected by the adverse impact so as to provide them with 'access to information on the purpose, nature and scale of the project, the duration of proposed project activities, and any risks to and potential impacts on such communities'. ${ }^{48}$ After consultation, any Action Plans adopted pursuant to Performance Standards 2-8 must be disclosed to affected communities. Thereafter, regular reports on and any material changes to the Action Plans must be disclosed in a format accessible to affected communities. ${ }^{49}$ Clients must also make certain sector-specific disclosures:

- For extractive industry projects, 'clients [are required to] publicly disclose their material project payments to the host government (such as royalties, taxes, and profit sharing), and [for new investments] the relevant terms of key agreements that are of public concern, such as host government agreements (HGAs) and intergovernmental agreements (IGAs)' ${ }^{50}$

- For infrastructure projects that will deliver essential services such as water, gas, or electricity, clients are encouraged to publicly disclose 'information relating to household tariffs and tariff adjustment mechanisms, service standards, investment obligations, and the form and extent of any ongoing government support' and, for newly privatised projects, 'concession fees or privatization proceeds'. Such disclosures will at times be made directly by the host government rather than the client. ${ }^{51}$

- Consultation. Clients are required to consult with potentially affected communities for all projects that may have adverse social and environmental impacts. Such consultation should be based on full prior disclosure of relevant materials and information; it should begin early in the assessment process and continue through implementation as risks and impacts arise, and it should allow for culturally appropriate decisionmaking processes, community language preferences, and the needs of particular vulnerable groups. The form of consultation should provide 'the affected communities with opportunities to express their views on project risks, impacts, and mitigation measures, and allows the client to consider and respond to them'. ${ }^{52}$ When projects pose 'significant adverse impacts', the goal of consultation is to 'ensure [affected communities'] free, prior and informed consultation and facilitate their informed participation'. This requires a more formal 'organized and iterative consultation', in which the client documents the process and incorporates communities' views into its decision-making. ${ }^{53}$ More specific forms of consultation are also required by other performance standards:

\footnotetext{
IFC 2006 Performance Standards, above n. 34, at 4 (Performance Standard 1, at para. 19). Id. at 5 (Performance Standard 1, at para. 20). 
- Performance Standard 5 (Land Acquisition and Involuntary Resettlement) requires consultation with and informed participation by affected communities (both displaced/resettled and host communities), as well as the establishment of a grievance mechanism. ${ }^{54}$ It also encourages clients to attempt 'negotiated settlement' with affected communities rather than relying on government expropriation or other compulsory methods of land acquisition. ${ }^{55}$

- Performance Standard 6 (Biodiversity Conservation and Sustainable Natural Resource Management) requires consultation with the project sponsor, managers, local communities, and other stakeholders when a project may impact an area designated as legally protected for the conservation of biodiversity. ${ }^{56}$

- Performance Standard 8 (Cultural Heritage) requires clients to consult with affected communities who can identify cultural heritage of importance, and to incorporate those community's views into the client's decision-making process. ${ }^{57}$

- Performance Standard 7 (Indigenous Peoples) reiterates the requirements of engagement as early as possible, disclosure, and ongoing and informed consultation with affected communities of indigenous peoples. Additionally, it specifies particular features that may make community engagement processes more culturally appropriate to indigenous peoples:

- Involve Indigenous Peoples' representative bodies (for example, councils of elders or village councils, among others)[;]

- Be inclusive of both women and men and of various age groups in a culturally appropriate manner[;]

- Provide sufficient time for Indigenous Peoples' collective decisionmaking processes[;]

- Facilitate the Indigenous Peoples' expression of their views, concerns, and proposals in the language of their choice, without external manipulation, interference, or coercion, and without intimidation[; and]

- Ensure that the grievance mechanism established for the project ... is culturally appropriate and accessible for Indigenous Peoples. ${ }^{58}$

Finally, clients must meet higher standards of 'free, informed, and prior consultation; and 'good faith negotiation' when a project may impact on an indigenous people's traditional or customary land, ${ }^{59}$ involve displacement or resettlement of an indigenous people from their traditional or customary land, ${ }^{60}$ or 'use the cultural resources, knowledge, innovations, or practices of Indigenous Peoples for commercial purposes' ${ }^{61}$

- Grievance Mechanism. If the client 'anticipates ongoing risks and adverse impacts on affected communities', it must establish a grievance mechanism 'scaled' to these risks. Such mechanism should receive complaints, respond promptly, and facilitate resolution of communities' concerns; it should also employ an 'understandable and transparent process that is

\footnotetext{
Id. at 20 (Performance Standard 5, at paras. 9-10).

Id. at 18 (Performance Standard 5, at para. 3).

Id. at 26 (Performance Standard 6, at para. 11, n.6).

Id. at 33 (Performance Standard 8, at para. 6).

IFC 2006 Performance Standards, above n. 34, at 29-30 (Performance Standard 7, at para. 9).

Id. at 30-31 (Performance Standard 7, at paras. 12-13).

60 Id. at 31 (Performance Standard 7, at para. 14).

61 Id. at 32 (Performance Standard 7, at para. 15).
} 
culturally appropriate and readily accessible to all segments of the affected communities' and do so 'at no cost and without retribution'. It cannot bar access to judicial or administrative remedies. ${ }^{62}$

While the 2012 Performance Standards maintains most of the same public participation requirements, they further emphasises that these requirements are flexible depending on 'the nature of a project, the scale of the risks, and the types of stakeholders or affected communities identified'. The new Performance Standard 1 defines 'stakeholder engagement' as an ongoing process that 'may include, in varying degrees, the following elements: handling of external communications and grievance redress, stakeholder analysis, disclosure of information, consultation and reporting to Affected Communities'. ${ }^{63}$ The new standards also introduce the concept of participatory monitoring, but couches it in very loose language, leaving this choice to the client's discretion. ${ }^{64}$ This flexibility responds to IFC's observation during the review process that traditional large-scale development projects falling into the highest risk category and requiring all public participation elements in fact make up a relatively small part of its portfolio. ${ }^{65}$ However, the potential consequence of granting additional discretion is that the new Performance Standards could make it harder to hold the IFC and its clients accountable for their acts and decisions.

Another significant aspect of the most recent Performance Standards is certain harmonisation with international human rights norms. First, they use the term 'free, prior, and informed consent' for indigenous peoples, implicitly referencing the international human rights principle from the UNDRIP, rather than keeping the 'free, prior, and informed consultation' requirement from the earlier standard. ${ }^{66}$ Second, they explicitly recognise 'the responsibility of business to respect human rights', referencing the International Bill of Human Rights and the eight International Labour Organisation conventions to define the term 'human rights', and recommend that businesses employ 'due diligence' to avoid infringing on human rights. ${ }^{67}$ This language mirrors and implicitly references the Guiding Principles on Business and Human Rights recently adopted by the UN Human Rights Council. It also connects the responsibility to respect human rights and to employ due diligence to the accessibility to 'an effective grievance mechanism that can facilitate early indication of, and prompt remediation of various project-related grievances'. ${ }^{68}$

\subsubsection{IFC Policy on Social and Environmental Sustainability, Disclosure Policy, and the Compliance Advisor/Ombudsman (CAO)}

While it is the clients' responsibility to comply with the eight Performance Standards, the IFC has corresponding responsibilities under the IFC's Policy on Social and Environmental Sustainability ${ }^{69}$ and its Disclosure Policy/Access to Information Policy. ${ }^{70}$

62 Id. (Performance Standard 1, at para. 23).

63 IFC 2012 Performance Standard 1, above n. 42, at para. 25 (emphasis added).

${ }^{64}$ Id. at para. 22 ('Where appropriate, clients will consider involving representatives from Affected Communities to participate in monitoring activities').

65 IFC, IFC's Policy and Performance Standards on Social and Environmental Sustainability and Policy on Disclosure of Information: Report on the First Three Years of Application, 29 July 2009, at 10 (indicating that during the three years after implementation of the Performance Standards, only 2.5 percent of projects approved have fallen in Category A, with 49.3 percent falling in Category B, 8.4 percent in Category C, and the remaining 39.8 percent falling in the separately analysed financial institution category).

66 IFC 2012 Performance Standard 1, above n. 42, at para. 36 (emphasis added).

${ }^{67}$ IFC, Policy on Environmental and Social Sustainability, 1 Jan. 2012, at para. 12 [hereinafter 2012 IFC Policy on Environmental and Social Sustainability]; IFC 2012 Performance Standard 1, above n. 44, at para. 3.

68 IFC 2012 Policy on Environmental and Social Sustainability, above n. 67 at para. 12.

69 Note that the 2012 version reverses the order of priority and is called 'Policy on Environmental and Social Sustainability'. See above n. 67.

70 IFC, IFC's Policy on Disclosure of Information, 30 Apr. 2006 [hereinafter IFC 2006 Disclosure Policy]; IFC, IFC Access to Information Policy, 1 Jan. 2012 (superseding the IFC 2006 Disclosure Policy) [hereinafter IFC 2012 Access to Information Policy]. 
The IFC's review and disclosure processes also contain public participation related requirements for the IFC itself. For Category A projects, the IFC must review all of the client's engagement process documentation and conduct its own investigation to determine whether the client's consultation and informed participation process led to 'broad community support' (BCS). BCS is defined as 'a collection of expressions by the affected communities, through individuals or their recognized representatives, in support of the project'. The IFC Policy clarifies that BCS may exist 'even if some individuals or groups object to the project' ${ }^{71}$ This requirement is retained in the 2012 Policy. $^{72}$

The 2006 and 2012 Policy describe the IFC's ongoing portfolio management responsibility after project approval as involving review of a client's periodic reports and independent site visits. However, the scope of its responsibilities is not always clear. The IFC standards, unlike those of some other MDBs, do not explicitly require that the client's commitments under the Performance Standards be incorporated into the terms and conditions of its financing agreements, ${ }^{73}$ In addition, the IFC, because it only does business with the private sector, does not provide for the public disclosure of its legal agreements. ${ }^{74}$

Review of IFC compliance with its policies falls within the competence of the Compliance Advisor/Ombudsman (CAO), which reports directly to the World Bank Group President. Affected communities may file complaints directly with the CAO. Such complaints are first processed by the Ombudsman, which assigns a neutral mediator to try to resolve the social or environmental issue through a range of alternative dispute resolution mechanisms. ${ }^{75}$ If a complaint cannot be resolved, the Ombudsman may refer it to the CAO's Compliance branch, which conducts an initial assessment and, if the situation warrants a compliance audit, forms a panel of experts to review IFC compliance. $^{76}$

\subsection{Inter-American Development Bank}

The Inter-American Development Bank Group (IDB) is the largest source of multilateral development finance in Latin America. ${ }^{77}$ It is comprised of three entities: the IDB that finances 'economic, social, and institutional development' by both the public sector/ sovereign-guaranteed and the private sector/non-sovereign guaranteed operations; the Multilateral Investment Fund (MIF), an IDB-administered trust fund that provides grants and investment to strengthen and expand the private sector; and the Inter-American Investment Corporation (IIC), a separately chartered international organisation that focuses particularly on small and medium enterprise financing. ${ }^{78}$ Whilst both the MIF and IIC focus exclusively on private sector operations (although at times jointly with state-owned enterprises), the IDB has tended to focus on public sector operations and on development of an enabling environment for the private sector. ${ }^{79}$ In fact, the Ninth

\footnotetext{
71 IFC 2006 Policy on Social and Environmental Sustainability, above n. 43, at para. 20.

72 IFC 2012 Policy on Environmental and Social Sustainability, above n. 67, at para. 28.

3 Elisa Morgera, 'Human Rights Dimensions of Corporate Environmental Accountability', in Human Rights in International Investment Law and Arbitration (Pierre-Marie Dupuy et al, eds. 2009) at 511, 515 (citing IFC review of its safeguards policy to support the general statement that 'corporate environmental accountability standards could be included in the loan agreements between the IFC ... and foreign investors, thereby becoming contractually binding').

74 IFC 2006 Disclosure of Information Policy, above n. 70, at para. 9(a). This has not been changed in the new disclosure policy. IFC 2012 Access to Information Policy, above n. 70, at para. 11(a)(i).

75 Compliance Advisor/Ombudsman [CAO], CAO Ombudsman, <http://www.cao-ombudsman.org/ howwework/ombudsman/> (last visited 7 Feb. 2011).

${ }^{76} \mathrm{CAO}, \mathrm{CAO}$ Compliance, <http://www.cao-ombudsman.org/howwework/compliance/> (last visited 7 Feb. 2011)

77 Inter-American Development Bank [IDB], About Us, <http://www.iadb.org/en/about-us/about-theinter-american-development-bank,5995.html> (last visited 17 Mar. 2011).

78 IDB, Annual Report 2009 (2009) at ii, 23, <http://idbdocs.iadb.org/wsdocs/getdocument. aspx? docnum $=35118293>$.

79 Id. at 23-25. This trend is borne out by the numbers. While financing to promote development of the
} 
General Capital Increase, agreed to in July 2010, mandates the IDB to develop a new strategy to 'foster development through the private sector'. ${ }^{80}$ This should result in increased IDB financing directly to private sector operations. ${ }^{81}$

Facilitating public or citizen participation in IDB activity has been a key priority since $1994 .{ }^{82}$ In May 2004, the IDB published a Strategy for Promoting Citizen Participation in Bank Activities that reflected a series of OAS resolutions and a regional strategy for increased public participation over the preceding decade. ${ }^{83}$ The 2004 Strategy aimed to 'establish general guidelines and criteria' for citizen participation based on the IDB's experience in employing various participatory procedures in the previous years ${ }^{84}$ and ultimately to develop 'a set of procedures that will systematically provide for public participation in the Bank's operational activities' ${ }^{85}$ The Strategy is partially formalized by the binding ${ }^{86}$ Environment and Safeguards Compliance Policy and the IDB's Disclosure of Information Policy (discussed below). ${ }^{87}$

\subsubsection{Public Participation Requirements for Private Sector Borrowers}

The 2004 Strategy defined 'participation' as 'the set of processes whereby citizens, via their governments or directly, can influence the decision-making process relating to [IDB's objectives and the operations it supports] ${ }^{88}$ Running throughout the elaboration of this definition are (1) the connection of participatory rights to the principles of representative democracy in the region and, simultaneously, (2) a clear concern that citizen participation should not undercut IDB's ultimate accountability to member state governments ${ }^{89}$ The IDB's three core elements of public participation, which vary from the Rio/Aarhus framework, are (1) information; (2) consultation; and (3) actual participation in implementation of project activities. ${ }^{90}$ As discussed below, the Policy outlines disclosure and consultation requirements for funding recipients, but does not require any project-level grievance mechanism.

The IDB Strategy goes beyond other MDB policies most notably by, in some circumstances, requiring that communities are both consulted in decision-making and given the opportunity to participate in actual project implementation. ${ }^{91}$ Like other

private sector through, e.g. improvements in the regulatory climate for business, totaled $\$ 9.7$ billion from 2004-2009, direct financing of private sector operations from 1994-2009 was just \$8.7 billion (eight percent of total IDB disbursements during the period). IDB, Private Sector Development Strategy Profile, at paras. 2.7-2.8, <http://idbdocs.iadb.org/wsdocs/getdocument.aspx?docnum=35573660>.

${ }_{80}$ Id. para. 1.2. (emphasis added). Note that this is in contrast to much of the previous policy goal to 'promote private sector development per se'. Id. para. 1.4.

81 Id.

82 This was a goal under the IDB's Eight Capital Increase, approved in 1994.

83 IDB, Strategy for Promoting Citizen Participation in Bank Activities, May 19, 2004, at 1-2, <http:// idbdocs.iadb.org/wsdocs/getdocument.aspx?docnum $=483088>$ [hereafter IDB Strategy].

${ }^{84}$ Id. at para.1.14. The participatory procedures already in place as of the 2004 Strategy included: '(i) consultation processes for projects with environmental and social impacts and those entailing population resettlements'; and '(iii) the inclusion in many loan and technical cooperation operations of innovative mechanisms explicitly designed to encourage public participation'. Id. at para.1.11.

85 Id. at para.1.14.

${ }^{86}$ IDB, IDB and Civil Society, <http://www.iadb.org/en/civil-society/the-idb-and-civil-society,6160. $\mathrm{html}>$ (last visited 24 Jan., 2010) (demonstrating that the 2004 Strategy is the only document referenced on the IDB's primary page for civil society). The IDB classification includes 'policies', which lay out rules binding on the organisation, guidance documents called 'strategies', which are broader statements that aim to implement new IDB mandates; and 'best practices' documents called policy notes, technical notes, and discussion papers. IDB, Operations Policies at the Inter-American Development Bank, $<\mathrm{http}: / / \mathrm{www} . i \mathrm{adb}$. org/en/about-us/operations-policies-of-the-inter-american-development-bank,6127.html> (last visited 24 Jan. 2011).

${ }_{87}$ Nevertheless, the Strategy still offers insight into the procedures by which IDB had previously imposed and intended to impose public participation requirements on private sector recipients of financing. IDB Strategy, above n. 83, at paras. 4.12-4.15.

88 Id. at para. 1.7 .

89 E.g. Id. at paras. $1.7-1.10,3.2$.

$90 \quad$ Id. at para. 5.1.

91 Id. Note that, as will be discussed further below, the IDB has its own information disclosure policy and 
MDB policies, however, it calls for an initial case-by-case determination about the need for public consultation, which is most often required in projects 'with significant environmental and social impacts. ${ }^{, 92}$ For a private sector loan, "early in the project preparation stage', the manager of the Private Sector Department will consult with the government of the country in which the project will occur in order to determine whether the project requires a consultation or participation plan and, if so, whether this is needed during the project planning or during the implementation stage. If a plan is developed, it will be incorporated as an annex to the loan document. IDB's Country Office will have a prominent role in facilitating either participation or consultation. ${ }^{93}$ Public participation during the implementation phase may involve either a 'community audit' (consultation), or the intended beneficiaries or civil society organisations actually executing some component of the project (participation). ${ }^{94}$ The Strategy is not clear as to the precise division of responsibilities between the borrower and the IDB. It does, however, elaborate upon several guiding principles for all forms of participationinclusiveness, pluralism, opportunity for timely input, transparency, efficiency, and cultural sensitivity. ${ }^{95}$

The 2006 Environment and Safeguards Compliance Policy formalised some of the procedures described in the Strategy. ${ }^{96}$ The policy expressly references the Rio Declaration, relevant trends in public participation, and the Equator Principles. ${ }^{97}$ The policy applies to all financial and non-financial support provided to both the public and private sector by the IDB and MIF. ${ }^{98}$ The basic framework involves initial, pre-approval screening and categorisation of projects based on an assessment of their environmental and other risks: ${ }^{99}$ Category A ('significant negative environmental and associated social impacts' or 'profound implications affecting natural resources'); Category B ('mostly local and short-term negative environmental and associated social impacts' capable of 'effective mitigation'); and Category C ('minimal or no negative environmental and associated social impacts'). ${ }^{100}$ Thereafter, the policy requires the following consultation and disclosure measures:

- Consultation. The borrower must conduct some environmental assessment, but the depth of the assessment and level of civil-society involvement depends on the classification. ${ }^{101}$ Both Category A and B projects must involve consultations with affected parties, ${ }^{102}$ and may include consultations with other interested parties. ${ }^{103}$ At least two consultations are required for Category A, during initial due diligence and later to review the environmental assessment document, and at least one for Category B,

\footnotetext{
dispute resolution mechanism, the Independent Consultation and Investigation Mechanism. See Id. at para. 1.11 .

${ }_{92}$ Id. at paras. 4.13-4.14.

93 Id. at para. 4.14

Id. at para. 4.13

95 Id. at para. 3.8.

96 IDB, Environmental and Safeguards Policy, (19 Jan. 2006), <http://idbdocs.iadb.org/wsdocs/ getdocument.aspx?docnum $=665902>$.

97 Id. at para. 1.3 ( identifying a series of regional trends, including, 'the increased role of civil society participation in the context of democratic processes; the process of convergence of policies and harmonization among multilateral and bilateral development institutions; the need to enhance development effectiveness; the increased role of private sector investments and public/private partnerships; [and] the sustainability commitments of leading private-sector financial institutions to the Equator Principles ....'). 98 Id. at para. 2.1.

99 According to the Policy definitions, risk is 'understood as the possibility that environmental, social, health and safety, governance or operation-specific factors may affect environmental sustainability of the operation. Safeguard risk assessment and management is an iterative process of identifying risk factors and taking action to manage risks at the country, portfolio, and operation level ' Id. at para. 6.1.

100 Id. at paras. $4.17-4.18$.

101 Id. at paras. 4.19.

102 Affected parties are defined in the Policy as 'individuals, group of individuals or communities who may be directly impacted by a Bank-financed operation. Such impacts may be positive or negative. Affected parties may designate representatives as part of the consultation process'. Id. at para. 6.1.

${ }_{103}$ Interested parties are defined in the Policy as 'individuals or groups who have expressed support or concern regarding a proposed or existing bank-financed operation'. Id. at para. 6.1.
} 
to review and formulate mitigation measures. ${ }^{104}$ The Policy's silence on Category $\mathrm{C}$ projects indicates that no consultation is required where there are no identified social or environmental risks. As part of the environmental assessment process, consultation is a responsibility of the borrower. ${ }^{105}$

- Disclosure. Implicit in the Policy's consultation requirements are certain disclosures that make consultation meaningful. The borrower must provide appropriate information at a location, time, and in a format that allows the affected parties to form an opinion. The final environmental assessment report(s) must also be disclosed. Finally, there is an ongoing obligation to inform affected parties about social and environmental mitigation measures once implementation begins. ${ }^{106}$

Notably missing from this Policy framework is any dispute resolution or grievance mechanism implemented directly by the borrower. Moreover, the requirement of actual affected community participation in project implementation does not seem to carry over from the Strategy.

A separate policy relates to projects that result in involuntary resettlement. ${ }^{107}$ In such projects, a preliminary resettlement plan must be part of the initial environmental assessment and must include evidence of consultation with affected communities. If the project is approved, 'timely and socio-culturally appropriate' consultations with a 'representative cross-section of the displaced and host communities' must take place during the design and implementation of the resettlement plan. ${ }^{108}$ The final resettlement plan is subject to approval by a specialized IDB Board and must provide for additional consultation with and participation of local entities, long-term sustainability, and a mechanism to resolve conflicting land claims. ${ }^{109}$ For indigenous or low-income ethnic minority communities, the borrower must show that the community has given 'informed consent to resettlement and compensation measures'. ${ }^{110}$ This final requirement echoes several specialized consultation and good-faith negotiation provisions contained in the IDB's extensive Operational Policy on Indigenous Peoples, ${ }^{111}$ but it does not specifically incorporate the international standard of 'free, prior, and informed consent'

\subsubsection{IDB Public Participation Responsibilities, IDB Disclosure Policy, and the Independent Consultation and Investigation Mechanism (MICI)}

Although the IDB delineates the responsibility of private and public sector borrowers for certain public participation requirements and describes the IDB's role in ensuring compliance, their inclusion in the same policy documents - such as the Environment and Safeguards Compliance Policy - may lead to some uncertainty about who has which responsibilities and when. Moreover, the treatment of public and private sector funding recipients without differentiation may at times cause confusion-for instance, public sector entities may need to undertake certain responsibilities (e.g. resolution of conflicting land claims) that may not be in the competence of a private sector entity. Anticipating such problems, the 2004 Strategy provided that the IDB Manager would

104 Id. at para. 4.20

105 Id. at paras. 4.19-4.20.

106 Id. at para. 4.20.

107 IDB, Involuntary Resettlement, (July 1998), <http://www.iadb.org/en/about-us/involuntaryresettlement,6660.html>.

108 Id.

109 The policy requires that a resettlement plan contain '(vii) provisions for consultation and involvement of local entities (public or private) that can contribute to execution and assume responsibility for the operation and maintenance of programs and infrastructure; ... and (x) a mechanism for the settlement of disputes regarding land, compensation and any other aspects of the plan'. However, it is not clear to what extent a private sector recipient of IDB funding would be responsible for actually implementing, e.g., the dispute resolution mechanism. Id.

110 Id.

111 IDB, Operational Policy on Indigenous Peoples \& Strategy for Indigenous Development, (July 2006), $<$ http://idbdocs.iadb.org/wsdocs/getdocument.aspx?docnum=2032081 $>$. 
consult with the host government before classifying the risk level of a private sector project and the IDB Country Office would take an active role in facilitating consultation or participation processes. ${ }^{112}$ Since neither process is mentioned in the Environment and Safeguards Policy, there may be room for confusion over respective roles and responsibilities. The Policy is clear, however, that all safeguard requirements and any mitigation measures resulting from community consultation should be annexed to the IDB loan or assistance agreements, subject to periodic review that may impact IDB's continued financing. ${ }^{113}$

As indicated above, the Policy's disclosure requirements for IDB funding recipients are based on general principles (e.g. 'appropriate information') rather than rules. By contrast, the IDB itself is subject to very clear and specific disclosure requirements in the IDB's Disclosure of Information Policy. However, this policy requires disclosure of key documents (e.g. loan agreements and environmental assessments) for public sector but not for private sector borrowers, for whom only a summary of such documents need be made public. ${ }^{114}$ Although often justified for business confidentiality reasons, such different disclosure requirements ${ }^{115}$ seem to risk impeding effective public participation in private sector projects.

Although IDB policy does not require the funding recipient to establish any projectlevel grievance mechanism, communities and individuals affected by IDB-financed projects have recourse to the Independent Consultation and Investigation Mechanism (MICI). The MICI, which replaced the Independent Investigation Mechanism in early 2010, is independent of IDB operations and reports directly to the IDB Board of Executive Directors. ${ }^{116}$ Any individual or community that is or will be negatively impacted by an IDB of MIC-supported project can file a complaint that alleges that the negative impact was caused by the IDB's failure to comply with its operational policies. The MICI has a two-phase response to the complaint. In the Consultation Phase, an appointed project ombudsman facilitates consultation between the complainant, the borrower/recipient, and other stakeholders in order to try to address the complaint. ${ }^{117}$ It is important to note that participation by each stakeholder in the consultation process is voluntary so that, for example, a private sector recipient may or may not choose to engage. ${ }^{118}$ In the Compliance Review Phase, a panel of independent experts reviews the IDB's performance to determine whether it has failed to comply with its obligations under its operational policies so as to cause adverse material impact to the complainant. However, the panel is not authorized to review the borrower's conduct.

\subsection{African Development Bank}

The African Development Bank Group is made up of three institutions: the African Development Bank (AfDB), which primarily finances public- and private-sector development-related projects, and also provides technical assistance to the public and private sectors and makes emergency loans; the African Development Fund (AfDF), which provides concessional loans and grants to low-income member states in the region; and the Nigeria Trust Fund, which also provides concessional financing to assist low-income member states with economic and social development. ${ }^{119}$ Initially, the AfDB only provided public sector loans, but in 1991, it began supporting the private

IDB Strategy, above n. 83, at para. 4.14.

113 IDB Environmental and Safeguards Policy, above n. 96, at para. 4.21.

114 E.g. IDB, Disclosure of Information Policy, (7 Aug. 2006), at 10, <http://idbdocs.iadb.org/wsdocs/ getdocument.aspx?docnum $=784916>$.

115 Id.

116 IDB, Policy Establishing the Independent Consultation and Investigation Mechanism of the InterAmerican Development Bank, (17 February 2010), at 1, <http://idbdocs.iadb.org/wsdocs/getdocument. aspx?docnum $=35074768>$.

117 Id. at paras. $38,46$.

118 Id. at para. 47

119 African Development Bank \& African Development Fund [AfDB-ADF], Annual Report 2009, (27-28 May 2010), at xi-xii, <http://www.afdb.org/fileadmin/uploads/afdb/Documents/Publications/Annual\%20 Report\%202009\%20EN\%20-\%20Web.pdf> [hereafter AfDB Annual Report 2009]. 
sector as well. ${ }^{120}$ Like the IDB, the AfDB has made a concerted effort to expand its private sector operations in recent years resulting in a sevenfold increase between 2004 and $2007 ;{ }^{121}$ as of 2009 , private sector financing approvals represented 20.7 percent of total AfDB approvals. ${ }^{122}$

There are a number of publicly available policy and guidance documents which relate to public participation requirements for the AfDB, including:

- AfDB Group Policy on Disclosure of Information (2005); ${ }^{123}$

- AfDB Group's Policy on the Environment (2004); ${ }^{124}$

- Involuntary Resettlement Policy (2003); ${ }^{125}$

- Environmental Assessment Procedures for Private Sector Operations of the African Development Bank (2001) (publicly available online only in French, although a variation on the policy that was later adapted for public sector operations is available online in English); ${ }^{126}$

120 African Development Bank Group, Strategy Update for the Bank's Private Sector Operations, (Jan.
2008), at iv, <http://www.afdb.org/fileadmin/uploads/afdb/Documents/Policy-Documents/PSO\%20
Strategy\%20\%28Eng\%29.pdf>.
121 Id. at 6 (citing figures of U.S. \$ 200 million in 2004 to U.S. \$ 1.4 billion in 2007).
122 AfDB, Annual Report 2009, above n. 119, at 21.
123 AfDB-ADF, African Development Bank Group Policy on Disclosure of Information, (Oct. 2005), $<$ http://www.afdb.org/fileadmin/uploads/afdb/Documents/Policy-Documents/10000004-EN-THEAFRICAN-DEVELOPMENT-BANK-GROUP-POLICY-ON-DISCLOSURE-OF-INFORMATION.PDF> [hereafter AfDB Disclosure Policy]. This policy is undergoing review through 2011, with a revised draft that has been released available at $<$ http://www.ebrd.com/pages/about/policies/pip/invitation.shtml $>$.

124 AfDB-ADF, African Development Bank Group's Policy on the Environment, (Feb. 2004), $<\mathrm{http}: / / \mathrm{www}$. afdb.org/fileadmin/uploads/afdb/Documents/Policy-Documents/10000027-EN-BANK-GROUP-POLICYON-THE-ENVIRONMENT.PDF>. According to an online summary, 'The Environmental Policy sets out the broad strategic and policy framework under which all Bank Group lending and non-lending operations will be made to promote environmentally sustainable development in Africa .... To help implement the policy, the Bank [uses] a set of approaches and [develops/strengthens] its procedures and guidelines, with particular focus on the full enforcement of the Environmental and Social Assessment Procedures for all lending operations of the Bank.' African Development Bank [AfDB] Group, Environment, <http:// www.afdb.org/en/topics-sectors/sectors/environment/angola/> (last visited 25 Jan. 2010) [hereafter AfDB Environment Page].

${ }_{125}$ AfDB-ADF, Involuntary Resettlement Policy, (Nov. 2003), <http://www.afdb.org/fileadmin/ uploads/afdb/Documents/Policy-Documents/10000009-EN-BANK-GROUP-INVOLUNTARYRESETTLEMENT-POLICY.PDF>. According to an online summary, 'The Bank Group involuntary resettlement policy is intended to address the involuntary displacement of people caused by Bank funded operations in public and private sector .... The borrowing agency has the primary responsibility for planning, implementing and monitoring resettlement issues. The borrower will be required to prepare a full resettlement plan (FRP) for any project that involve a significant number of people (200 or more persons) who would need to be displaced with a loss of assets, or access to assets or reduction in their livelihood. For any project involving the resettlement of less than 200 persons, an abbreviated resettlement plan will be released together with the environmental annex of the Bank's Appraisal Report. The full resettlement plan and the abbreviated resettlement plan should be posted in the Bank's Public Information Centre (PIC) and the Bank's web site for public review and comments in accordance to the Bank's disclosure policy and the Bank's Environmental and Social Assessment Procedures (ESAP 2001)'. AfDB Environment Page, above n. 124.

126 AfDB-ADF, Procédures en Matière d'Etude Environnementale Relatives aux Operations du Secteur Privé de la Banque Africaine du Développement, (May 2000) <http://www.afdb.org/fileadmin/uploads/ afdb/Documents/Policy-Documents/ESAP\%20pour\%20Prive\%20Secteur\%20Operation.pdf> [hereafter AfDB ESAP Procedures for the Private Sector]. According to an online summary, 'The environmental review procedures have been prepared for the review of prospective projects to be considered for financing under the Private Sector window .... The environmental review procedures describe the various steps that task managers in the Private Sector Department must follow to ensure that projects are environmentally sustainable and socially responsible. The procedures allocate responsibilities for the various steps in the review process. The procedures are complemented by a number of annexes containing additional requirements to be met by the projects. Private Sector operations must comply with applicable Bank's environmental and social policies and procedures. In sectors where no such policies or guidelines exist, the Private Sector department applies relevant internationally recognized standards'. AfDB Environment Page, above n. 124. See also AfDB-ADF, Environmental and Social Assessment Procedures for African Development Bank's Public Sector Operations, June 2001, <http:/www.afdb.org/fileadmin/uploads/afdb/ Documents/Project-related-Procurement/ESAP\%20for\%20Public\%20Sector\%20Operations.pdf>. 
- Integrated Environmental and Social Assessment Guidelines (2003) (unclear whether version available online is final version as it has track changes); ${ }^{127}$

- Guidelines for Strategic Impact Assessment (2003) (not available online); ${ }^{128}$

- Cooperation with Civil Society Organizations - Policy and Guidelines on $(2001) ;{ }^{129}$ and

- Handbook on Stakeholder Consultation and Participation (2001). ${ }^{130}$

Most of these are applicable to both private and public sector operations. Yet, for the environmental and social assessment procedures, the AfDB first released a document specific to its private sector operations and then adapted it for the public sector. While there are differences in form, the substantial processes outlined in the two are in essence the same, although the title to the private sector document refers only to environmental assessment procedures, while the public sector version refers to environmental and social assessment procedures. ${ }^{131}$

As indicated above, some of the publicly available documents on the AfDB website do not appear complete. In other instances, more than one document addresses the same or similar issues, with overlapping requirements. In addition, it is often unclear whether all the documents are currently in force or if one has been superseded. Finally, the AfDB's online information does not clearly identify which documents are binding on Bank staff. Such information access problems may make it difficult for potential funding recipients to understand their obligations and for affected/interested parties to formulate realistic expectations regarding participation in any particular Bank funded operation. However, the AfDB is reportedly reviewing several of its policies, notably its Information Disclosure Policy and the integrated environmental assessment policies. ${ }^{132}$ It is hoped that this review process will clarify the uncertainties identified above.

\footnotetext{
127 AfDB, Integrated Environmental and Social Assessment Guidelines, (Oct. 2003), <http://www.afdb. org/fileadmin/uploads/afdb/Documents/Policy-Documents/Integrated\%20Environmental\%20and\%20 Social\%20Impact\%20Assesment\%20Guidelines.pdf $>$. According to an online summary, "The IESIA Guidelines are tools used in the implementation of the Bank's Environmental and Social Assessment Procedures. The major objective of the IESIA Guidelines' is to provide guidance to the staff of the Bank and RMCs on how to adequately consider crosscutting themes while assessing the environmental and social impacts of a project'. AfDB Environment Page, above n. 124.

${ }_{128}$ Referred to and summarised on the AfDB website, but actual document not available. According to the online summary, the Strategic Impact Assessment (SIA) is 'a systematic process for evaluating the environmental consequences of proposed policy, plan or program initiative in order to ensure they are fully included and appropriately addressed at the earliest stage of decision-making on a par with social and economic considerations'. AfDB Environment Page, above n. 124.

129 AfDB-ADF, Cooperation with Civil Society Organization - Policy and Guidelines, (Oct.1999), <http:// www.afdb.org/fileadmin/uploads/afdb/Documents/Policy-Documents/10000024-EN-COOPERATIONWITH-CIVIL-SOCIETY-ORGANIZATIONS-POLICY-AND-GUIDELINES.PDF> [hereafter AfDB CSO Policy and Guidelines].

130 AfDB, Handbook on Stakeholder Participation in ADB Operations, (2001), <http://www.afdb. org/fileadmin/uploads/afdb/Documents/Policy-Documents/Handbook\%20on\%20Stakeholder\%20 Consultaion.pdf $>$ [hereafter AfDB Stakeholder Participation Handbook]. As summarised online: 'The purpose of the Handbook is to help Bank staff and Regional Member Country (RMC) counterparts better understand what participation actually means in practice. It provides guidelines and outlines specific actions that Bank staff should take to promote participation at every stage of the Bank's project cycle.... The development of the Handbook stems from the Bank's recognition of participation as an essential factor to the achievement of its overarching objectives of poverty reduction and sustainable development, notably through enhanced project quality, ownership and sustainability, empowered beneficiaries and long-term capacity building and self-sufficiency', AfDB Environment Page, above n. 124.

${ }_{131}$ Note that there is some confusion since the 2001 French-language policy applicable to the private sector refers only to environmental assessment procedures, while the 2001 English-language policy applicable to the public sector refers to environmental and social assessment procedures (ESAP).

132 Private e-mail from AfDB staff member to authors, March 30, 2011 (on file with authors).
} 


\subsubsection{Public Participation Requirements for Private Sector Borrowers}

Despite these general challenges, the publicly available AfDB policy framework does lay out a series of procedures for public participation in environmental (and perhaps social) risk assessment which appear quite similar to those employed by the IDB and the World Bank's Safeguards. Like these other MDBs, the AfDB's policy contains more information on the AfDB's organisational procedures and what public participation must occur than on the borrower's specific responsibilities. Moreover, public participation requires project-level disclosure and consultation, but no project-level grievance mechanism.

According to the AfDB's Environmental and Social Assessment Procedures, when the Private Sector Operations Department (now renamed the Private Sector and Microfinance Department or PSMD) receives a request for funding, the request goes to the Environment and Sustainable Development Unit (ESDU/OESU) for initial screening of environmental (and social) risks. The project is categorized by risk levels similar to those employed by the IDB or the World Bank's Safeguards: Category 1 (projects that 'could have an important impact of a sensitive, widespread, or unprecedented nature'); Category 2 (projects 'whose potential impacts on the human populations or zones of environmental importance are less serious than those in Category 1', are localized, and can be mitigated through preventative measures); and Category 3 (no negative environmental impact). ${ }^{133}$ This categorisation determines what level of environmental (and social) assessment must be undertaken and the extent of required public consultation. ${ }^{134}$

For Category 1 projects, the 'project promoter'(funding recipient) must, in the course of the environmental assessment process, organise 'consultations with stakeholders, who comprise affected groups, civil society organisations, and local authorities, about the social and environmental impacts of the project' and must 'take their opinions into consideration. ${ }^{135}$ The promoter should begin consultations as soon as possible. In order for consultations to be effective, the promoter must also make relevant information available in a format that is accessible to all stakeholders. ${ }^{136}$ The consultation process should continue through the preparation of the environmental assessment and should include a round of consultations after the promoter prepares and discloses a nontechnical summary of the final report. ${ }^{137}$ Following all consultations, the promoter must include in the final report a section describing the consultation process, the stakeholders' concerns, the promoter's responses, and the measures taken to incorporate these concerns into the design and execution of the project. ${ }^{138}$ The promoter must continue to consult with stakeholders throughout the project's implementation and is required to detail these consultations in each annual report submitted to the AfDB.${ }^{139}$ Moreover, if a Category 1 project planning was completed prior to AfDB involvement, the Bank may ask the project promoter to determine whether supplementary public consultations and information disclosure are necessary ${ }^{140}$ (although it is unclear under what standards the AfDB reviews the borrower's determination of such necessity).

For Category 2 projects, the AfDB may determine whether there are particular questions for which consultation between the project promoter and affected communities should be required early in the project planning phase. ${ }^{141}$ No other requirements are given for Category 2. The silence on Category 3 projects may suggest that no consultation is required.

\footnotetext{
133 AfDB ESAP Procedures for the Private Sector, above n. 126, at para. 21 (authors' translation). As with the IDB, there is also a category for private sector financial institutions, which will not be addressed in this paper.

134 Id. at paras. 27-28.

135 Id. at para. 28 (authors' translation).

136 Id. (authors' translation).

137 Id. at para. 29

138 Id. at para. 30

139 Id. at para. 31.

140 Id. at para. 32

141 Id. at para. 33.
} 
According to the AfDB Environmental and Social Assessment Procedures for the Private Sector, all consultations should follow and be based on disclosure of information in accordance with the AfDB's Policy on Disclosure of Information. ${ }^{142}$ The Policy on Disclosure of Information currently in force details public disclosures associated with the environmental assessment process. For Category 1 projects, the environmental assessment 'shall be released in the borrowing country project area at some public place accessible to potential beneficiaries, affected group and local CSOs' and subsequently published on the AfDB website; ${ }^{143}$ the same is true for an executive summary of the assessment prepared by Bank staff, but only with the consent of the borrower in question. ${ }^{144}$ For Category 2 projects, the management plan developed to mitigate negative social and environment impacts must be publicised to affected groups in the country, and via the AfDB website thirty days prior to the plan's approval and incorporation into the loan agreement. ${ }^{145}$ In the case of involuntary resettlement, the required resettlement plans will be disclosed together with other required environmental assessment disclosures. ${ }^{146}$ The policy language does not make clear whether the Bank or the promoter is responsible for preparing the documents or disseminating them as required.

\subsubsection{AfDB Disclosure Policy and the Independent Review Mechanism (IRM)}

The AfDB Policy details other general public disclosure requirements that fall exclusively to the Bank and relate to the effectiveness of project-level public participation. These include disclosure of a Prospective Project Brief (PPB) for all public and private sector projects while the project is in the preparation stages $;{ }^{147}$ of final loan and grant agreements, with no restriction for agreements with private sector entities; ${ }^{148}$ and of 'a summary report on the progress and status of project implementation highlighting important indicators of progress in attainment of project development objectives'. ${ }^{149}$ The only difference in the treatment of the public and the private sector in the disclosure policy is that the policy restricts disclosure of 'financial, business or proprietary information of private sector entities' without the entity's consent if such information is disclosed during the AfDB's pre-contract approval deliberative process. ${ }^{150}$

Like other MDBs, the AfDB offers adversely affected parties the Independent Review Mechanism (IRM). The IRM serves both a compliance review function, in which it reviews alleged AfDB noncompliance with its policies, and a problem-solving function, in which it mediates between complainants and other interested parties, including the borrower if it agrees to participate. Both functions are open to persons adversely affected by an AfDB-financed private sector project; however, for private sector projects, the IRM can only review AfDB compliance with its environmental and social policies. ${ }^{151}$

\footnotetext{
${ }_{142}$ Id. at para. 28. Note there is some legal uncertainty about this reference, because the Environmental Assessment Procedures for the Private Sector was issued in 2001, so this presumably refers to an earlier version of the disclosure policy than that currently in force and available online; the Procedures also elaborate specific public disclosure requirements for Category 1 and 2 projects. Which of these two specific policies accurately describes the obligations of a private sector project promoter is a matter of some uncertainty, although perhaps not material.

${ }_{143}$ AfDB Disclosure Policy, above n. 123, at paras. 4.24-4.25.

144 Id. at paras. 4.26-4.27.

145 Id. at para. 4.28.

146 Id. at para. 4.29 .

147 Id. at paras. 4.14-4.17.

148 Id. at para. 4.53 .

149 Id. at para. 4.30

150 Id. at para. 5.8.

151 AfDB, Independent Review Mechanism, <http://www.afdb.org/en/about-us/structure/independentreview-mechanism/\#> (last visited $30 \mathrm{Jan}, 2011$ ).
} 
Like other such mechanisms, the IRM can only receive requests that relate to an act or omission by the AfDB that is not in compliance with the Bank's policies and procedures and not to the borrower's activity. ${ }^{152}$

\subsection{Asian Development Bank}

Like the other regional MDBs, the Asian Development Bank (AsDB) finances both public and private sector operations and has recently undertaken to make private sector operations a more integral part of its strategy. ${ }^{153}$ In 2010, AsDB approved U.S. \$1.44 billion in loans to the private sector compared to U.S. $\$ 7.69$ billion to the public sector. ${ }^{154}$

AsDB is the MDB that most recently completed a review of its Safeguard Policy, adapting it to reflect prior implementation experience and the changed regional and global context. Among the changes it identified were: (1) 'higher [regional] expectations in relation to transparency and citizen participation'; and (2) an increasing willingness among the private sector 'to adopt progressive investment practices that are socially and environmentally responsible and that may go beyond mere compliance with regulations if they have a clear business case for doing so'. ${ }^{155}$ As part of the review process, the AsDB canvassed recent developments in other MDBs' social and environmental policies and used these to inform its own decisions, ${ }^{156}$ ensuring that its policy requirements are consistent with those of the World Bank, IFC, and the European Bank for Reconstruction and Development, in order to facilitate harmonisation when it co-funds projects with these MDBs. ${ }^{157}$

Even prior to the most recent review, the AsDB safeguards were more streamlined than other MDBs' similar policies. They consist of just three policies, concerning the environment, ${ }^{158}$ involuntary resettlement, and indigenous peoples. The recent policy review aimed, inter alia: (1) to enhance its consultation and participation requirements by standardising those contained in the environment, involuntary resettlement, and indigenous peoples policies in order to create higher common standards $;{ }^{159}$ and (2) to adapt the policies to better suit the private sector project cycle, which typically means a tighter timetable for AsDB due diligence. ${ }^{160}$ In terms of structure, the same 2009 Policy applies to both public and private sector projects. ${ }^{161}$ A single Safeguard Review Procedure consolidates the AsDB's internal review responsibilities ${ }^{162}$ and disclosure requirements that explicitly supersede the previous AsDB Public Communications Policy. ${ }^{163}$ The borrower's responsibilities are separated out in a series of Safeguard Requirements, ${ }^{164}$ which follow an approach similar to the documentary breakdown between the IFC's Procedure and its Performance Standards. ${ }^{165}$

\footnotetext{
152 AfDB Group, Independent Review Mechanism Operating Rules and Policies, (16 June 2010), at 3, $<$ http://www.afdb.org/fileadmin/uploads/afdb/Documents/Compliance-Review/IRM\%20Operating\%20 Rules\%20and\%20Procedures\%20-\%2016\%20June\%202010.pdf $>$.

153 Asian Development Bank [AsDB], Private Sector Operations (Nonsovereign), <http://www.adb.org/ About/Private-Sector/default.asp> (last visited 30 Jan. 2011).

${ }_{154}$ AsDB, Operations, <http://www.adb.org/About/operations.asp > (last visited 30 Jan, 2011).

155 AsDB, Policy Paper: Safeguard Policy Statement, June 2009, at 2-3, <http://www.adb.org/Documents/ Policies/Safeguards/Safeguard-Policy-Statement-June2009.pdf $>$ [hereafter AsDB SPS Policy Paper].

156 Id. at 3, Attachment 1 (Experience of Other Multilateral Financial Institutions).

157 Id. at 12 .

158 Note that more specific safeguards for, e.g., forests or biodiversity are contained in other sector policies.

159 See Id. at 10.

160 See Id. at 12-13.

161 Id. at 15

162 AsDB, Operations Manual/Bank Policies: Safeguard Review Procedures, OM Section F1/OP, 4 Mar. 2010, available at http://www.adb.org/Documents/Manuals/Operations/OMF01-4Mar2010.pdf [hereafter ADB Safeguard Review Procedures].

163 AsDB, Disclosure, <http://www.adb.org/disclosure/> (last visited 30 Jan. 2010).

164 AsDB SPS Policy Paper, above n. 155, at Appendix 1 (Safeguard Requirements 1: Environment), Appendix 2 (Safeguard Requirements 2: Involuntary Resettlement), and Appendix 3 (Safeguard Requirements 3: Indigenous Peoples).

165 Id. at 15
} 


\subsubsection{Borrower Responsibilities in the Safeguard Requirements}

Similar to other MDBs' safeguard policies, the initial step in any AsDB project screening process includes identification of potential risks and application of a three-tiered categorisation scheme that dictates the level of environmental assessment, resettlement plan, or indigenous peoples plan that will be required. However, under the Safeguard Requirements on environment, involuntary resettlement, and indigenous peoples, the borrower must utilise to some degree the three elements of public participation, which are outlined in a similar way to the IFC Performance Standards. These general requirements are:

- Information Disclosure. The borrower is required to submit certain documents to AsDB for disclosure on its website with explicit timing requirements aimed at allowing adequate time for review and comment prior to approval. Additionally, these documents and other relevant information must be provided to affected people and interested stakeholders in a timely manner and in an accessible language and format. Provisions must be made so that illiterate people can also access information. ${ }^{166}$

- Consultation and Participation. The core requirement incumbent on the borrower is 'meaningful consultation' with affected people and concerned stakeholders that facilitates their informed participation, corresponds to the level of identified risks, and is recorded in the project preparation documents. 'Meaningful consultation' is defined as:

A process that (i) begins early in the project preparation stage and is carried out on an ongoing basis throughout the project cycle; (ii) provides timely disclosure of relevant and adequate information that is understandable and readily accessible to affected people; (iii) is undertaken in an atmosphere free of intimidation or coercion; (iv) is gender inclusive and responsive, and tailored to the needs of disadvantaged and vulnerable groups; and (v) enables the incorporation of all relevant views of affected people and other stakeholders into decision making, such as project design, mitigation measures, the sharing of development benefits and opportunities, and implementation issues. $^{167}$

In projects involving involuntary resettlement, the borrower must consult with affected people, their host communities, and civil society organisations, and take particular care to include disadvantaged or vulnerable populations, such as those without legal tenure. ${ }^{168}$ In projects affecting indigenous peoples, meaningful consultation aims to facilitate their 'informed participation in (i) designing, implementing, and monitoring measures to avoid adverse impacts on them or, when avoidance is not possible, to minimize, mitigate, and compensate for such effects; and (ii) tailoring project benefits that accrue to them in a culturally appropriate manner'. ${ }^{169}$ Special attention should be paid to cultural context and women and youth. In the event of serious disagreements, the borrower must attempt 'good faith negotiations' with indigenous peoples. ${ }^{170}$

- Grievance Mechanisms. The borrower must establish a mechanism to receive and resolve complaints from affected people. The mechanism must be transparent, responsive in a prompt manner, culturally appropriate, accessible, sensitive to the needs of vulnerable populations, and

\footnotetext{
166 AsDB SPS Policy Paper, above n. 155, at Appendix 1 (Safeguard Requirements 1: Environment, at paras. 17-18), Appendix 2 (Safeguard Requirements 2: Involuntary Resettlement, at paras. 26-27), and Appendix 3 (Safeguard Requirements 3: Indigenous Peoples, at paras. 20-21).

167 Id. at Appendix 1 (Safeguard Requirements 1: Environment,at para.19), Appendix 2 (Safeguard Requirements 2: Involuntary Resettlement,at para.28), and Appendix 3 (Safeguard Requirements 3: Indigenous Peoples, at para.10).

168 Id. at Appendix 2 (Safeguard Requirements 2: Involuntary Resettlement,at para. 28).

169 Id. at Appendix 3 (Safeguard Requirements 3: Indigenous Peoples, at para. 10).

170 Id. at Appendix 3 (Safeguard Requirements 3: Indigenous Peoples, at paras. 11-12).
} 
commensurate with the scale of project and associated risks. Resort to this mechanism should not bar access to the country's judicial or administrative remedies. ${ }^{171}$

Beyond these general requirements, the Safeguard Requirements include specific instances in which other forms of consultation or participation are incumbent on the borrower. Many of these, as with the preceding general requirements, echo the IFC Performance Standards. For instance, for projects affecting 'physical cultural resources', the borrower must also consult with the national or local authorities charged with managing such resources. ${ }^{172}$ Borrowers are also encouraged to attempt negotiated settlement through meaningful consultation with communities to be resettled rather than resorting to expropriation. ${ }^{173}$ As a final example, when projects involve commercial development of certain resources important to indigenous people, the borrower must go beyond usual consultation and obtain the indigenous people's 'consent', constituting a collective expression of 'broad community support'. ${ }^{174}$

\subsubsection{Safeguard Review Procedures and the Accountability Mechanism}

Under the new AsDB policies, the responsibility for implementing public participation requirements and other social and environmental safeguard clearly falls to the borrower; while the separate Safeguard Review Procedures outline specific steps that the AsDB project team will undertake during each of the project stages (identification, design and preparation, implementation, and completion) to ensure that the borrower complies with the Safeguard Requirements. ${ }^{175}$ Specifically, the project team conducts initial screening and tentatively classifies the project according to negative environment impacts, scale of involuntary resettlement (if any) and impact on indigenous peoples. ${ }^{176}$ Based on this classification, which must be confirmed by the chief compliance officer, the team determines the level of consultation and participation required. ${ }^{177}$ Importantly, the Procedures recognise that 'classification is an ongoing process', meaning that a project's classification can be modified if changes in circumstances later warrant this. ${ }^{178}$ During the project design and implementation phase, the project team determines whether the borrower has complied with information disclosure requirements and advises on how to conduct and document meaningful consultation. For projects in the highest risk category, the project team must actually participate in consultations in order to 'understand the concerns of the project-affected people'. ${ }^{179}$ No direct AsDB participation in consultations is required for lower-risk projects.

If a project is approved, the project team must ensure that 'legal agreements include adequate covenants to address implementation of the [Safeguard Requirements]' and that all final plans agreed upon by borrower, affected communities and the AsDB are referenced. Moreover, if relevant to the project type, the legal agreement should oblige the borrower to 'incorporate safeguard requirements in bidding documents and civil work contracts' so that they will also bind third parties who are contracted to assist in project implementation. ${ }^{180}$ Throughout implementation, the AsDB reviews the borrower's compliance with commitments described in these legal agreements. ${ }^{181}$ Review of projects with social or environmental impacts includes periodic 'supervision

171 Id. at Appendix 1 (Safeguard Requirements 1: Environment,at para. 20), Appendix 2 (Safeguard Requirements 2: Involuntary Resettlement,at para. 29), and Appendix 3 (Safeguard Requirements 3: Indigenous Peoples, at paras. 22).

172 Id. at Appendix 1 (Safeguard Requirements 1: Environment,at para. 46).

173 Id. at Appendix 2 (Safeguard Requirements 2: Involuntary Resettlement,at para. 25).

174 Id. at Appendix 3 (Safeguard Requirements 3: Indigenous Peoples, at paras. 30-36).

175 See AsDB Safeguard Review Procedures, above n. 162.

176 Id. at paras. 4-11.

177 Id. at para. 4.

178 Id. at para. 5.

179 Id. at para. 19.

180 Id. at para. 24.

181 Id. at para. 25. 
missions' to project sites. ${ }^{182}$ All reports submitted by the borrower during project implementation must also be disclosed online. ${ }^{183}$ If the borrower does not meet the commitments reflected in legal agreements, it must 'develop and implement a corrective action plan' and the AsDB may exercise its legal remedies under the contract. ${ }^{184}$

Finally, beyond the public participation mechanisms directly required of the private sector borrower and enforced by the AsDB in the course of the normal project cycle, project-affected communities have recourse to the Accountability Mechanism, which offers two functions: (1) a problem-solving ('consultation') phase, which is a mandated first step for all complaints; and then (2) an investigatory phrase ('compliance review') in which an independent panel reviews allegations that the AsDB has severely failed to comply with its policies. ${ }^{185}$ Since its 2003 redesign, the Accountability Mechanism has been open to complaints relating to private sector operations. ${ }^{186}$ It should be noted that the AsDB is currently reviewing its Accountability Mechanism Policy based on public comments, and the results of the review (perhaps including a new policy) were due in July 2011. ${ }^{187}$

\subsection{European Bank for Reconstruction and Development (EBRD)}

Unlike the other regional MDBs, the European Bank for Reconstruction and Development (EBRD) primarily finances the private sector based on its mandate of fostering open and democratic market economies in Europe, Russia, and Central Asia. Its mandate also obliges it to promote environmentally and socially sustainable development. ${ }^{188}$ Not surprisingly, given its private sector focus, the EBRD has adopted an environmental and social policy that is similar to the IFC's framework. It has an Environmental and Social Policy (2008) that is implemented through its Environmental and Social Procedures (last updated 2010). The Bank also has produced a series of ten subjectspecific Environmental and Social Performance Requirements that lay out borrower responsibilities. With democratisation a key component of the EBRD mission, these include quite strong public participation requirements. Additionally, the EBRD has a Public Information Policy (2008), which addresses Bank-level disclosure requirements, and an independent Project Complaint Mechanism.

\subsubsection{Performance Requirements on Public Participation}

The most significant structural difference between the EBRD Performance Requirements and the IFC Performance Standards is that the EBRD separates the requirements that relate to information disclosure and stakeholder engagement (Performance Requirement 10) from those that relate to environmental and social appraisal and management (Performance Requirement 1). However, in both performance standards, it instructs that they should be read 'in conjunction' with one another and provides a chart summarising the objectives of each of these two cross-cutting sets of requirements in order to illustrate

\footnotetext{
182 Id. at para. 26.

183 Id. at para. 29.

184 Id. at para. 28.

185 AsDB, Accountability Mechanism, <http://www.adb.org/accountability-mechanism/> (last visited 30 Jan. 2011).

${ }_{186}$ AsDB, Proposal for a New ADB Accountability Mechanism: A Two-Step Approach of Consultation and Compliance Review, at paras. 43-46, Appendix 1 (Accountability Mechanisms at Other Multilateral Development Banks) <http://www.adb.org/Documents/Policies/ADB_Accountability_Mechanism/ accnt303.asp? $p=$ policies $>$ (reviewing similar mechanisms at the IFC, IDB, and EBRD to justify its policy change toward private sector operations).

187 AsDB, Accountability Mechanism Review, <http://www.adb.org/AM-Review/default.asp > (last visited 14 Oct. 2011). At the time of publication (Oct. 2011), the results of this review process were not publicly available.

188 ActionAid et al, above n. 1, at 5-8; see also, European Bank for Reconstruction and Development [EBRD], Mission, <http://www.ebrd.com/pages/about/what/mission.shtml> (last visited 30 Jan. 2011). Note that financial reports do not separate private and public sector operations.
} 
where they overlap. ${ }^{189}$ The EBRD approach thus recognises that public participation has an independent value beyond its utility in assessing and mitigating environmental and social risks.

Accordingly, Performance Requirement 10 frames stakeholder engagement more positively as 'an essential part of good business practices and corporate citizenship, and a way of improving the quality of projects' and 'central to achieving enhanced community benefits'. ${ }^{100}$ It explicitly approves the Aarhus Convention approach to the three elements of public participation, but does not limit these to environmental measures. ${ }^{191}$ Instead, the three elements form part of its definition of 'stakeholder engagement' as 'an ongoing process involving (i) the client's public disclosure of appropriate information so as to enable meaningful consultation with stakeholders, (ii) meaningful consultation with potentially affected parties, and (iii) a procedure or policy by which people can make comments or complaints' ${ }^{192}$ The object of this engagement is for the clients 'to build and maintain a constructive relationship with their stakeholders'. ${ }^{193}$

Performance Requirement 10 begins with a presentation of general requirements for disclosure and stakeholder engagement and goes on to stipulate a series of specific stages, procedures, and mechanisms that the client is required to employ. Firstly, stakeholder engagement must be ' $[(1)]$ free of manipulation, interference, coercion, and intimidation, and [(2)] conducted on the basis of timely, relevant, understandable and accessible information, [(3)] in a culturally appropriate format ${ }^{\prime}{ }^{194}$ Secondly, engagement requirements should be scaled to the particular project and its associated risks, based on a 'stakeholder assessment' conducted by the borrower early in the project cycle and a separate assessment by EBRD as part of its due diligence, and may include additional steps to those specified in Performance Requirement $10 .{ }^{195}$ The EBRD assessment process classifies projects as Category A if they "could result in potentially significant and diverse adverse future environmental and/or social impacts and issues which, at the time of categorisation, cannot readily be identified or assessed and which require a formalised and participatory assessment process carried out by independent third party specialists in accordance with the PRs' ${ }^{196}$ To assist with identifying such projects, the Policy also provides a non-exhaustive list of project types that are likely to fall into Category A. ${ }^{197}$ As a separate harmonisation measure, Performance Requirement 10 states that the borrower must comply with any public participation requirements imposed by applicable national law, including a state's domestic implementation of international law. ${ }^{198}$

Following on from these general requirements, the specific stages and steps set out in Performance Requirement 10 can be summarised as follows:

\section{During Project Preparation}

- Stakeholder Analysis. As a first step, the borrower is required to identify stakeholders classed as 'affected parties' and 'other interested parties', ${ }^{199}$ and describe in adequate detail how each will be affected by 'actual

\footnotetext{
189 EBRD, Performance Requirement 10: Information Disclosure and Stakeholder Engagement, (May 2008) at para. $4,<\mathrm{http} / / / \mathrm{ww}$ w.ebrd.com/downloads/about/sustainability/ESP PR10 Eng.pdf $>$ [hereafter EBRD PR10]; EBRD, Performance Requirement 1: Environmental and Social Appraisal Mechanism, May 2008,at para. 3, <http://www.ebrd.com/downloads/about/sustainability/ESP_PR01_Eng.pdf $>$ [hereafter EBRD PR1]

190 EBRD PR10, above n. 189, at para. 1.

191 Id. at para. 2.

192 Id. at para. 3.

193 Id. at para. 4.

194 Id. at para. 6.

195 Id. at para. 7.

196 EBRD, Environmental and Social Policy, May 2008, para. 20 [hereafter EBRD ESP].

197 Id. Appendix 1 (Category A Projects).

198 EBRD PR10, above n. 189, at para. 7.

199 Id. at para. 8 .
} 
or perceived impacts' ${ }^{200}$ This includes identifying those who will be 'differentially or disproportionately affected by the project because of their vulnerable or disadvantaged state'. ${ }^{201}$ Employees are always regarded as stakeholders. ${ }^{202}$ 'Affected parties' should always be prioritized over 'other interested parties' in any information disclosure or consultation efforts. ${ }^{203}$ For Category A projects, the borrower must engage in a 'scoping process' and open the draft stakeholder engagement plan and other scoping documents to comment by stakeholders. ${ }^{204}$

- Stakeholder Engagement Plan. In this subsequent stage, the borrower informs EBRD as to how it will communicate with each identified group of stakeholders throughout the project. The plan should also describe the grievance mechanism to be used. ${ }^{205}$

- Information Disclosure. For negatively impacted communities, the borrower should disclose the following relevant information rather than just particular documents:

- the purpose, nature, and scale of the project[;]

- the duration of proposed project activities[;]

- any risks to and potential impacts with regard to environment, worker health and safety, public health and safety and other social impacts on communities, and proposed mitigation plans[;]

- the envisaged consultation process, if any, and opportunities and ways in which the public can participate[; and]

- time/venue of any envisaged public meetings, and the process by which meetings are notified, summarised, and reported. ${ }^{206}$

Note that this includes important procedural information not always captured in other standards. It must be in the local language, culturally appropriate, and accessible to stakeholders, including vulnerable groups. ${ }^{207}$ Any mitigation plans agreed upon must be disclosed as non-technical summaries or in their full form for Category A projects. ${ }^{208}$ There are also additional disclosure and specific timing requirements for Category $\mathrm{A}$ projects that involve certain types of environmental assessments. ${ }^{209}$

- Meaningful Consultation. Where there are significant risks or adverse impacts for affected people, the borrower must engage in culturally and otherwise appropriate meaningful consultation in order to provide affected parties with 'opportunities to express their views on project risks, impacts, and mitigation measures' and to allow 'the client to consider and respond' ${ }^{210}$ More specifically, meaningful consultation:

- should be based on the disclosure of relevant and adequate information including, where appropriate and relevant, draft documents and plans, prior to decisions being taken when options are still open[;]

- should begin early in the environmental and social appraisal process[;]

- will focus on the social and environmental risks and adverse impacts, and the proposed measures and actions to address these[; and]

\footnotetext{
Id. at para. 9.

Id.

Id.

Id. at para. 8.

204 Id. at para. 10.

205 Id. at para. 11.

206 Id. at para. 12

207 Id. at para. 13

208 Id. at para. 14

209 Id. at para. 18

210 Id. at paras. 15-16.
} 
- will be carried out on an ongoing basis as the nature of issues, impacts and opportunities evolves. ${ }^{211}$

Category A projects must meet a higher standard to guarantee affected communities' 'informed participation' through iterative consultation during decision-making processes. ${ }^{212}$ If communities will suffer severe and permanent adverse impact without commensurate benefits, the borrower should seek to determine possible beneficial community development projects, although it is not clear who would implement such a project. ${ }^{213}$

\section{During Project Implementation}

- Ongoing Engagement and Reporting. Throughout the entire project implementation period, the borrower must engage with affected communities in such a way as to solicit their feedback on effectiveness of implementation. The borrower must also periodically provide certain relevant information and report to both affected communities and other external interested parties. ${ }^{214}$

- Grievance Mechanism. The borrower must establish a grievance mechanism commensurate with the scale of the project and associated risks, which should be able to receive, promptly respond to, and facilitate resolution of complaints. It should protect complainants' privacy and not bar access to judicial or administrative remedies. ${ }^{215}$

Higher or more detailed requirements for public participation are also found in Performance Requirement 5: Land Acquisition, Involuntary Resettlement and Economic Displacement, which emphasises the importance of the required consultation and grievance mechanism for resettled and host communities; ${ }^{216}$ Performance Requirement 6: Biodiversity, which specifically requires consultation with the managers of legally protected areas and surrounding local communities; ${ }^{217}$ and Performance Requirement 8: Cultural Heritage. These requirements generally reflect those in the 2006 IFC standards, although the EBRD's accompanying explanatory language is clearer and more accessible. In addition, the EBRD's Performance Requirement 7: Indigenous Communities explicitly looks to international human rights law in order to recognise the principle that indigenous communities must give 'prior, informed consent' in certain projects. ${ }^{218}$ This requirement supplements the 'good faith negotiation' and 'prior consultation' requirements, which echo the standards of other MDBs.

\subsubsection{EBRD Policies and Project Complaints Mechanism}

The EBRD's new framework clearly delineates the clients' responsibilities in a format designed to help them understand what they will be required to do and when in order to qualify for EBRD funding. The EBRD's role and responsibilities are spelled out in the Social and Environmental Policy and the Public Information Policy. The Social and Environmental Policy follows the more recent trend of giving the EBRD both more specific monitoring obligations and stronger enforcement capacity. Accordingly, the EBRD reviews information provided and offers guidance to assist the client in meeting

211 Id. at para. 15.

212 Id. at para. 17.

213 Id. at para. 20.

214 Id. at paras. 21-23.

215 Id. at paras. 24-25.

216 EBRD, Performance Requirement 5: Land Acquisition, Involuntary Resettlement and Economic Displacement, (May 2008), at paras. 12-13.

217 EBRD, Performance Requirement 6: Biodiversity, (May 2008), at para. 15.

218 EBRD, Performance Requirement 7: Indigenous Communities, (May 2008), at paras. 4, 31 (referring to the U.N. Declaration on the Rights of Indigenous Peoples). 
the requirements set out in Performance Requirement 10 during project planning. ${ }^{219}$ It uses the stakeholder engagement plan as an integral part of project appraisal. ${ }^{220}$ However, the EBRD may also conduct its own public consultation 'to gauge stakeholder views' for some Category A projects. ${ }^{221}$

In addition, the loan agreement between the EBRD and the client will incorporate both social, environmental, and stakeholder engagement requirements, including specific reference to applicable Performance Requirements which the client must apply, and provisions delineating EBRD's rights and remedies in the event of client noncompliance. ${ }^{222}$ Both the client and the EBRD have responsibilities for monitoring compliance during project implementation. ${ }^{223}$ The EBRD continues monitoring so long as it has a financial stake and this includes not just reviewing clients' regular reports, but also conducting field missions and periodically sending independent/third party monitors. ${ }^{224}$ If the client fails to comply with obligations set out in the legal agreements, the EBRD may first allow the client to undertake remedial measures before exercising its contractual rights and remedies. ${ }^{225}$

In its Public Information Policy, the EBRD lays out guiding principles that clearly highlight some of the tensions between public participation and private sector operations. On the one hand, the EBRD commits itself to transparency and open communication with stakeholders in both its institutional and operational activities. ${ }^{226}$ On the other hand, it states that a 'business-sensitive partnership with sponsors and contractual counterparties is necessary to allay concerns about client confidentiality which could affect their willingness to work with the Bank' ${ }^{227}$ This tension is echoed throughout the policy, particularly with regard to project-related information. The essential disclosure is the 'project summary document' or PSD, which the EBRD prepares for each private or public sector project according to specified requirements. ${ }^{228}$ For private sector projects, the policy requires that the PSD must be disclosed at least thirty days before the EBRD Board of Directors considers the project for approval, but offers a loophole: 'unless the Bank's client or co-financing institution provides sound reasons for not releasing the document' ${ }^{229}$ However, the loophole does not seem to apply to the required disclosures of social and environmental information, particularly the assessment documents that must be publicised 120 days before a private sector Category A project is considered for approval. ${ }^{230}$ Finally, the Public Information Policy includes a long list of information that is confidential; ${ }^{231}$ for example, this list leaves it unclear whether the EBRD would release its legal agreements with private sector borrowers. ${ }^{232}$

Finally, in addition to the project-level grievance mechanism required in certain types of projects, project-affected communities also have recourse to the EBRD's Project Complaint Mechanism (PCM). Like similar mechanisms at other MDBs, the PCM has two functions: problem-solving, which aims at facilitating dialogue between EBRD clients ('project sponsors') and complainants; and compliance, which reviews and assesses EBRD's compliance with its Social and Environmental Policy and Public Information Policy. Project sponsors are not contractually required to participate in the PCM's problem-solving process; rather, their participation is voluntary. Moreover,

219 EBRD ESP, above n. 196, at para. 14.

220 Id. at para. 26.

221 Id. at para. 25.

222 Id. at para. 33.

223 Id. at para. 35.

224 Id. at para. 36.

225 Id. at para. 37.

226 EBRD, Public Information Policy, (Sept. 2008), at 2-3 (basic principles 1 and 3). Note that the EBRD opened this policy for public review during the first half of 2011. A revised policy is expected in late 2011

227 Id. at 3 (basic principle 4).

228 Id. at para. D.3.1.1.

229 Id. at para. D.3.1.2.

230 Id. at para. D.3.4.1

231 Id. at para. D.3.4.1.

232 Id. at para. E.1.1-1.9. 
the problem-solving and compliance processes are separate; claimants may select to attempt either or both processes. ${ }^{233}$

\section{The Role of MDBs in Developing and Harmonizing Public Participation Requirements and Increasing Accountability for the Private Sector: Conclusions and Recommendations}

As the preceding discussion illustrates, there is a trend toward harmonisation of public participation standards across the development finance industry. In fact, this trend extends beyond MDB financing since many private financial institutions have adopted the Equator Principles. Thus, both public and private sources of funds clearly seem to be moving toward the IFC Performance Standards. This trend, which is consistent with the MDBs' commitment to the Paris Declaration, ${ }^{234}$ should ensure convergence of all funders towards the perceived best industry practices for both effective and efficient public participation. Nevertheless, the subsequent discussion highlights certain aspects of the harmonisation trend that are noteworthy.

\subsection{Clarifying Borrower and Bank Responsibilities}

One clear trend in the MDBs' policies, reflecting the model of the IFC Performance Requirements, is the move toward policies that delineate the borrowers' and MDBs' respective responsibilities for public participation in the project. Under such policies, both private and public sector borrowers have the primary responsibility for implementing participation requirements and the MDBs' role is limited to strategic advising, monitoring, and occasional independent review. Such delineation, which began in the 2006 IFC standards and has been followed by the AsDB and EBRD, is attractive as it helps both the borrower and MDB to understand their responsibilities and it should facilitate greater accountability for the project. However, there is a danger that if this division of responsibility is not well defined and easily understood that its net effect could be to reduce the ability of outside stakeholders to understand the respective responsibilities for public participation of the MDB and the private borrower. This, in turn, could make it harder to hold them accountable for their respective roles in ensuring public participation.

In this regard, it is important to note that accountability requires clear and accessible operational policies, procedures, and standards that can be understood by all stakeholders. This, in turn, is dependant on the MDBs disclosing sufficient information in order to help stakeholders determine if their interests are being adequately addressed in particular projects, while at the same time providing reasonable protection to proprietary information in private sector projects. Striking the appropriate balance between these two competing objectives is particularly challenging with regard to MDB-funded private sector projects.

\subsection{Increasing MDB Engagement with the Private Sector}

One consequence of the fact that private sector operations represent a growing portion of MDB portfolios is that the concerns of the private sector are likely to be reflected more clearly in the evolving standards. This can also be seen in the tendency of some

\footnotetext{
233 EBRD ESP, above n. 196, at para. 42; Private e-mail from EBRD staff member to authors, April 13, 2011 (on file with authors).

234 Paris Declaration and the AAA, above n. 28. The international organisations adhering to the Paris Declaration and the AAA include the World Bank, Inter-American Development Bank, Asian Development Bank, African Development Bank, European Bank for Reconstruction and Development, and the European Investment Bank. OECD, Countries, Territories and Organisations Adhering to the Paris Declaration and AAA: <http://www.oecd.org/document/22/0,3746,en_2649_3236398_36074966_1_1_1_1,00.html > (last visited 7 Feb. 2011).
} 
MDBs, for example AsDB and EBRD, to follow the IFC approach. This creates some risk of undue deference to either the confidentiality of business information in disclosure requirements or to the private sector's interest in having streamlined consultation requirements. Provided the MDBs pay careful attention to the interests of all stakeholders in formulating their public participation requirements, these risks can be managed. Failure to do so, however, could result in weaker participatory rights for more vulnerable stakeholders in MDB-funded projects. In this regard, it should be noted that the MDBs' standards are often the primary means for ensuring effective participation by affected communities in private sector project planning and implementation processes.

\subsection{Growing Significance of MDB Activities for International Soft Law}

The harmonisation trend highlights the growing legal relevance and significance of the MDBs' standards in regard to participation in private sector projects funded by the MDBs. In the first place, some of the MDBs' standards make explicit reference to international legal instruments such as the Rio Declaration, the Aarhus Convention, and the U.N. Declaration on the Rights of Indigenous Peoples. Most of the MDBs' standards also utilise key principles from these instruments, such as free, prior, and informed consent for indigenous communities.

Second, the MDBs are contributing to our understanding of these legal principles. This follows from the fact that these standards are being interpreted and applied by the various actors taking part in MDB operations, including the MDB staff, the borrower's staff, the personnel in the project-level grievance mechanisms, and the experts serving on the MDBs' independent accountability mechanisms. Since the acts and decisions of all these bodies and actors are often limited to fact finding or resolving a specific issue or dispute, they do not establish binding precedents. Nevertheless, they provide important empirical data on how participation works in practice and serve as examples of how to understand, interpret, and apply the MDBs' policies, which, either explicitly or implicitly incorporate the international legal principles applicable to participation. In this way, the MDBs are influencing and contributing to the development of international law on public participation.

This suggests that the MDBs, perhaps despite themselves, are becoming a leading source of the evolving soft law standards on participation in development projects. This follows from the fact that the MDBs, in the course of their operations, regularly handle numerous public participation cases. Their treatment of these cases creates precedents concerning what constitutes sufficient public participation and how to interpret the applicable standards in specific cases. Accordingly, MDBs should more explicitly acknowledge and embrace their role in international law making, looking both at the experience of other MDBs and other more formal legal sources that interpret participatory rights in contexts beyond development finance. Moreover, they should systematically develop this case law through rigorous, transparent, and inclusive project monitoring, evaluation, and dispute resolution that captures and reports both the successes and challenges of private sector implementation of public participation.

\subsection{The Way Forward}

This paper, by providing a systematic and comparative analysis of the standards on public participation currently followed by international and regional MDBs, has aimed to provide a useful resource. It is, however, only a starting point. Building on it, legal scholars could contribute to the development of the international law of participation by collecting and analysing the large amounts of raw project information available through MDBs' websites and through the complaints received and handled by the MDBs' independent review mechanisms to extract the manifold lessons they may contain about how these institutions interpret and apply their standards on public participation. 


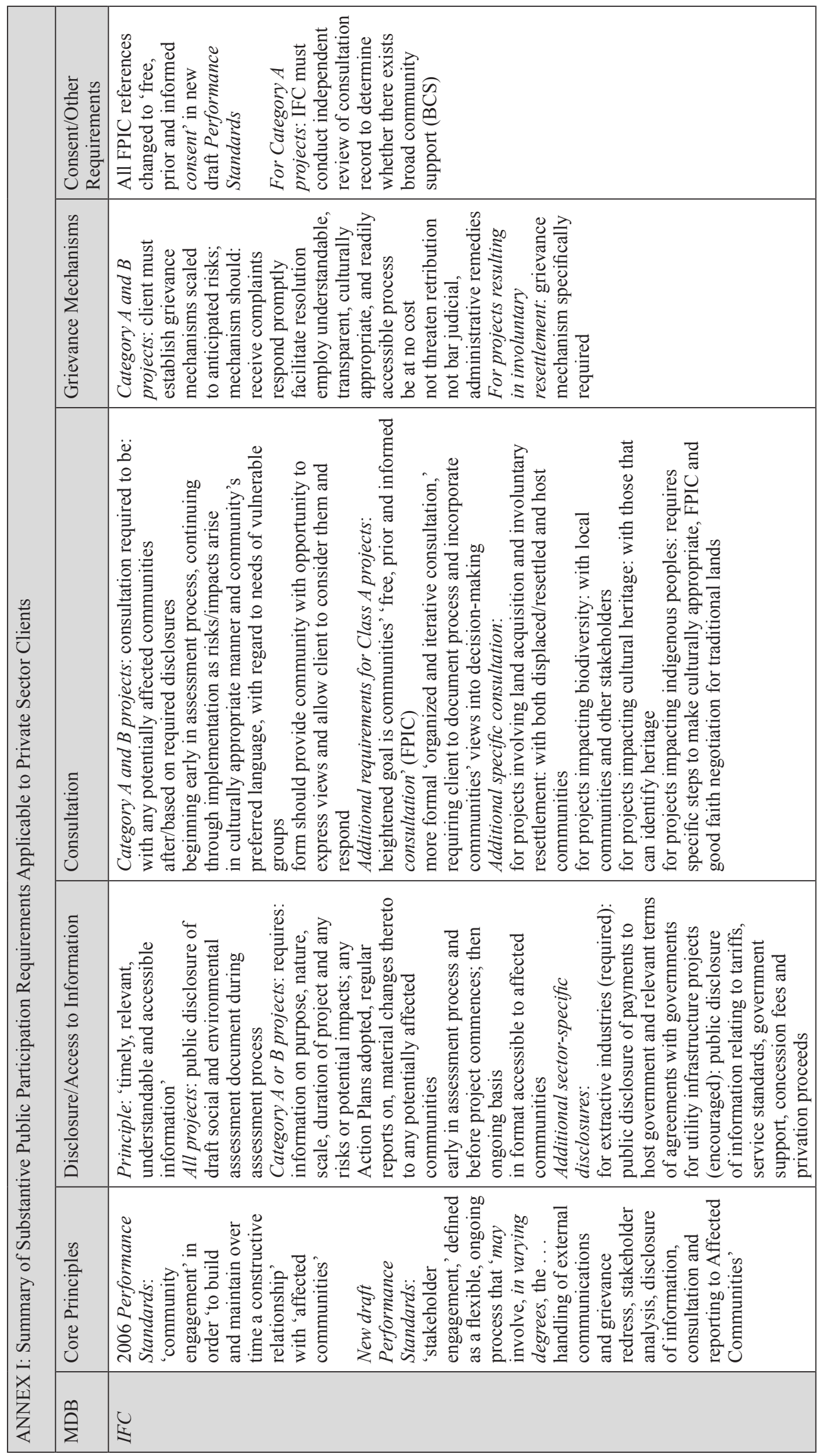




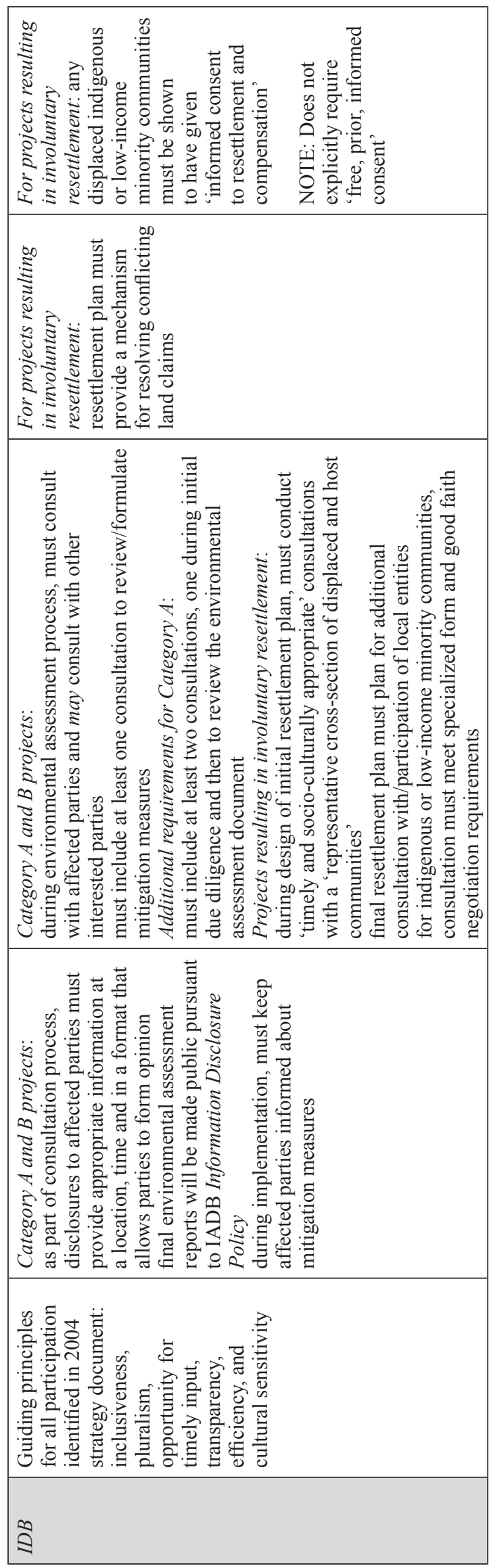




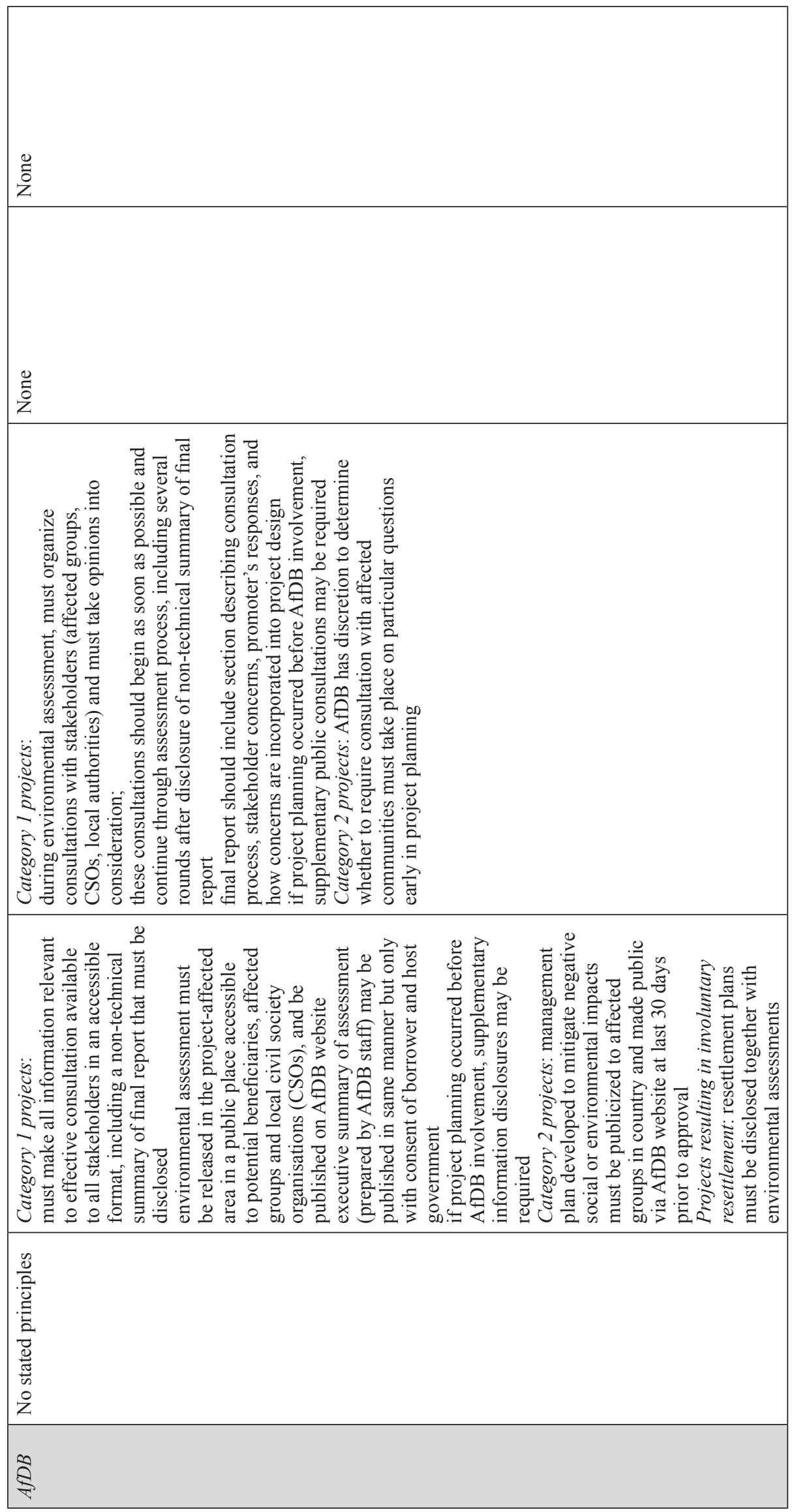




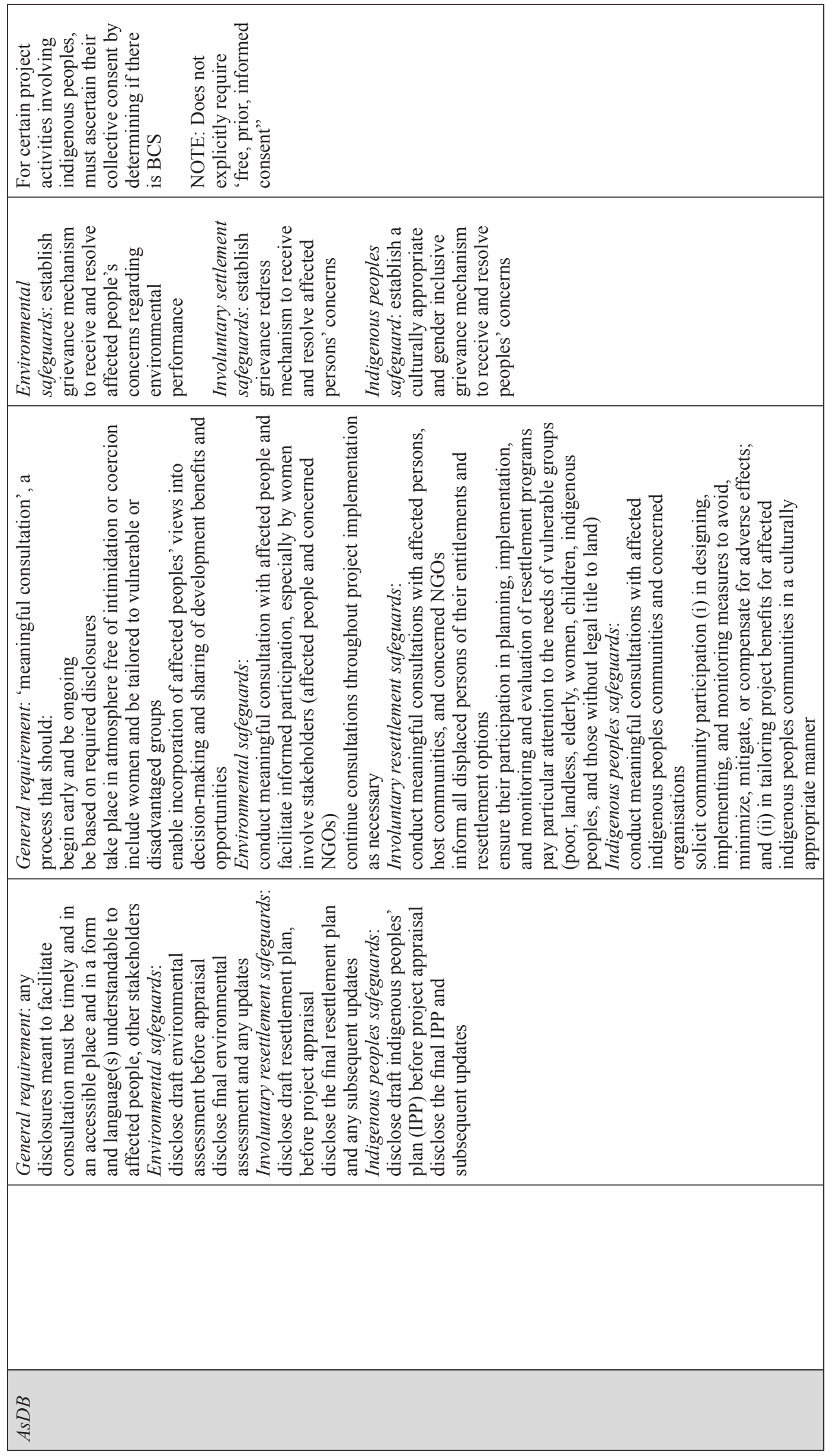




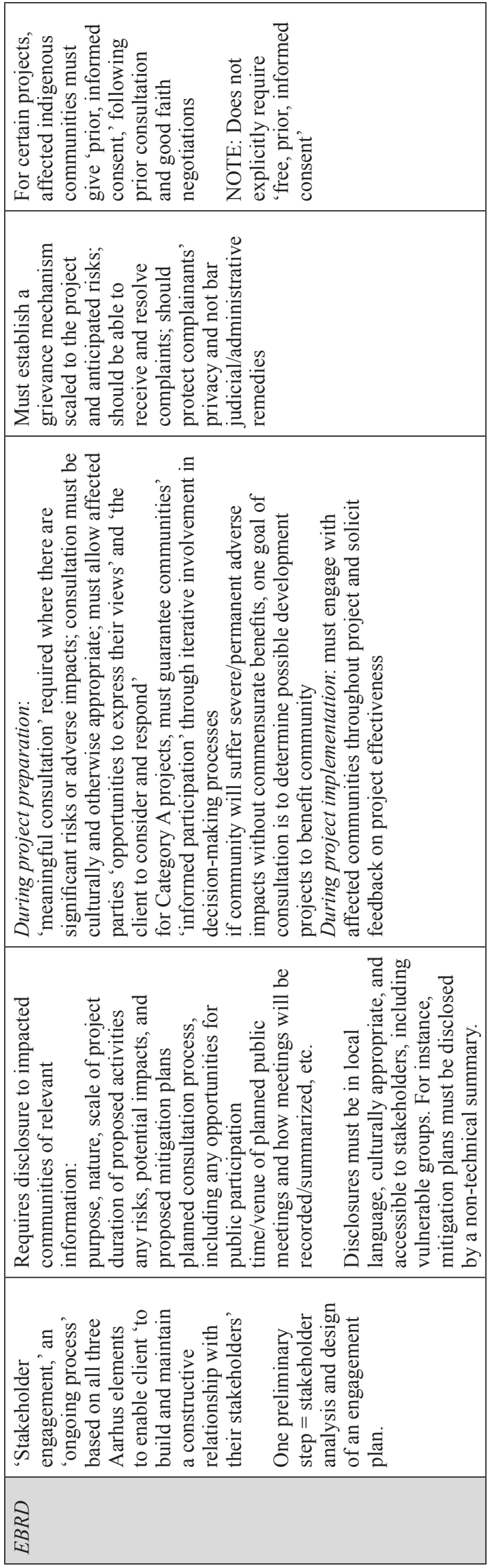

